Article

\title{
Design, Synthesis, and Biological Evaluation of Pyridineamide Derivatives Containing a 1,2,3-Triazole Fragment as Type II c-Met Inhibitors
}

\author{
Hehua Xiong ${ }^{\dagger}$, Jianxin Cheng ${ }^{\dagger}$, Jianqing Zhang, Qian Zhang, Zhen Xiao, Han Zhang, \\ Qidong Tang * and Pengwu Zheng * \\ School of Pharmacy, Jiangxi Science \& Technology Normal University, Nanchang 330013, China; \\ 18296154955@163.com (H.X.); cjx3159@163.com (J.C.); zhang1405474771@163.com (J.Z.); \\ 15797966937@163.com (Q.Z.);xz950420@163.com (Z.X.); zbl1045762244@163.com (H.Z.) \\ * Correspondence: tangqidongcn@126.com (Q.T.); zhengpw@jxstnu.edu.cn (P.Z.); Tel.: +86-791-8380-2393 (P.Z.) \\ + These authors contribute equally to this work.
}

Academic Editor: Qiao-Hong Chen

Received: 21 November 2019; Accepted: 10 December 2019; Published: 18 December 2019

check for updates

\begin{abstract}
A series of 4-(pyridin-4-yloxy)benzamide derivatives containing a 1,2,3-triazole fragment were designed, synthesized, and their inhibitory activity against A549, HeLa, and MCF-7 cancer cell lines was evaluated. Most compounds exhibited moderate to potent antitumor activity against the three cell lines. Among them, the promising compound B26 showed stronger inhibitory activity than Golvatinib, with $\mathrm{IC}_{50}$ values of 3.22, 4.33, and $5.82 \mu \mathrm{M}$ against A549, HeLa, and MCF-7 cell lines, respectively. The structure-activity relationships (SARs) demonstrated that the modification of the terminal benzene ring with a single electron-withdrawing substituent (fluorine atom) and the introduction of a pyridine amide chain with a strong hydrophilic group (morpholine) to the hinge region greatly improved the antitumor activity. Meanwhile, the optimal compound B26 showed potent biological activity in some pharmacological experiments in vitro, such as cell morphology study, dose-dependent test, kinase activity assay, and cell cycle experiment. Finally, the molecular docking simulation was performed to further explore the binding mode of compound B26 with c-Met.
\end{abstract}

Keywords: 4-(pyridin-4-yloxy)benzamide; 1,2,3-triazole; c-Met; inhibitor

\section{Introduction}

Cancer has become a serious threat to human life and health [1,2]. c-Met tyrosine kinase is a kind of type III tyrosine kinase, which is closely related to cellular activities [3] such as growth, reproduction, metastasis, etc. However, abnormal expression of c-Met kinases in cells usually triggers the occurrence, invasion, and metastasis of various cancer diseases [4]. c-Met kinase has been found overexpressed in various cancer cells and has become an attractive target for cancer treatment [5,6]. Nowadays, developing small molecule c-Met kinase inhibitors has become a hotspot in the treatment of human cancer [7].

c-Met inhibitors are classified as type I and type II inhibitors according to the binding mode of inhibitors with c-Met. Usually, c-Met inhibitors of type I are single-target inhibitors that bind to the hinge region of the ATP pocket, and c-Met inhibitors of type II are multitarget inhibitors that bind to the hinge region and an extra hydrophobic pocket $[8,9]$. With the development of biology and pharmacology, the intracellular mechanisms have been elucidated, and research in small molecule inhibitors has made significant progress. Type II c-Met inhibitors possess more potent inhibitory activity and better tolerance to drug resistance through binding to kinases of multiple types. Cabozantinib, a c-Met inhibitor of type II, was approved by the FDA for treatment of prostate cancer in 2012. Some representative c-Met inhibitors (type II) in the clinical trial phase are listed in Figure 1, including 
Golvatinib, BMS-777607, Altriatinib, and TAS-115 [10-12]. Furthermore, according to the structure characteristics of inhibitors, the skeleton of c-Met inhibitor (type II) was summarized into blocks A, B, $\mathrm{C}$, and D by our research group, as shown in Figure 1 [13].
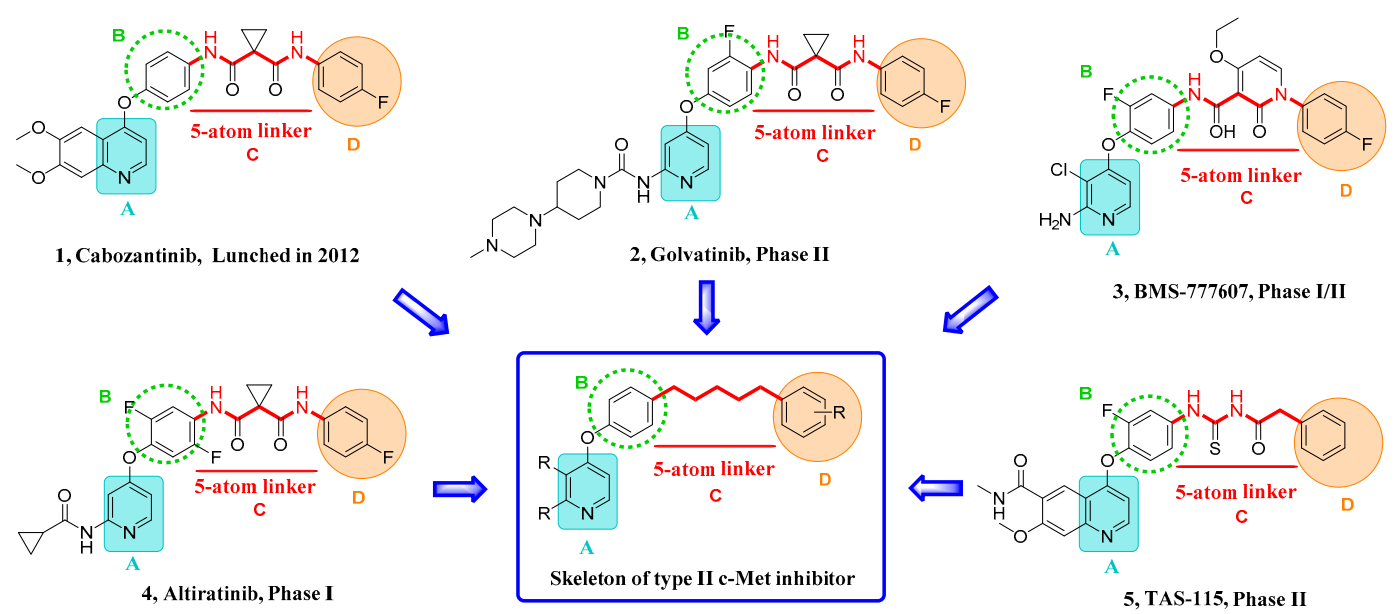

3, BMS-777607, Phase I/II

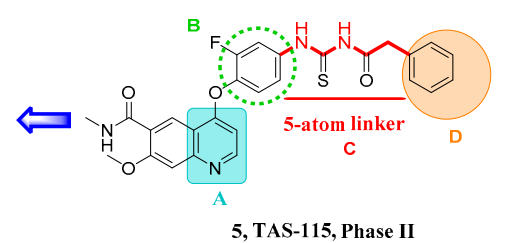

Figure 1. Some representative c-Met inhibitors of type II and the summarized skeleton.

We explored the SARs of c-Met inhibitors (type II) bearing pyridinamide structure using Golvatinib as a lead compound in this study. In order to guide our modification of the lead compound, a molecular docking simulation of Golvatinib and c-Met protein was performed, as shown in Figure 2. The docking results indicated that blocks $\mathrm{A}$ and $\mathrm{C}$, which possessed hydrogen bonding interactions with residues Met1160, Asp1222, and Lys1110, played a key role in maintaining the inhibitory activity against c-Met. Therefore, the modification was mainly concentrated on blocks A and C. Firstly, a pyridylamide structure in block A, including hydrogen bond donor and hydrogen bond acceptor atoms, was introduced into the meta position of pyridine in order to enhance the interaction with the hinge region residues, and then some alkyl chains bearing morpholine or thiophene groups were connected to the terminal of the pyridine amide structure for better water solubility of compounds. Then, a 1,2,3-triazole fragment with good biological activity and two hydrogen bond acceptor atoms was introduced to block $\mathrm{C}$ for more tight combination between the compounds and c-Met. In addition, considering the steric hindrance problem [14], H/F atoms and different substituents were introduced in blocks $\mathrm{B}$ and D, respectively, to explore their effects on biological activity of target compounds. Finally, a series of small molecule inhibitors containing the 1,2,3-triazole fragment were designed, synthesized, and biologically evaluated.
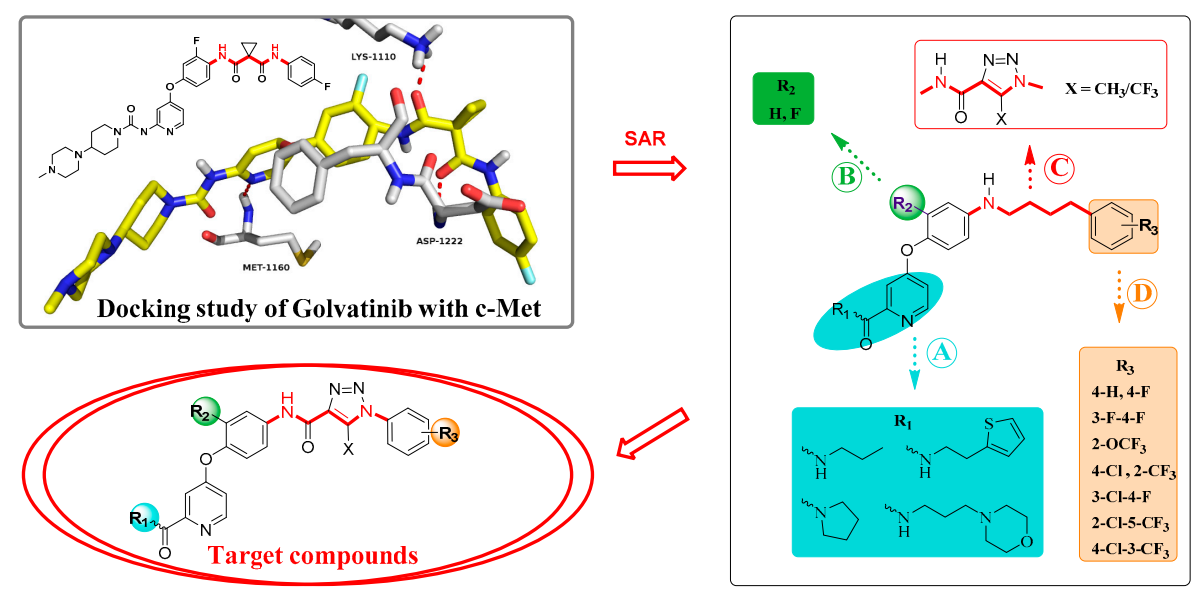

Figure 2. Design strategy of target compounds based on the molecular simulation and structure-activity relationships (SARs). 


\section{Results and Discussion}

\subsection{Chemistry}

The synthesis route of target compounds B1-B27 is shown in Scheme 1. Firstly, the commercially available pyridinecarboxylic acid 6 was reacted with $\mathrm{SOCl}_{2}$ using $\mathrm{NaBr}$ as catalyst to yield 4-chloropicolinoyl chloride 7, which was then converted into ethyl 4-chloropicolinate 8 with ethanol. Next, 4-chloropicolinate 8 was subjected to nucleophilic substitute with $p$-nitrophenol or 2-fluoro-4-nitrophenol using chlorobenzene as solvent to give picolinate analogues $\mathbf{9 a - 9} \mathbf{b}$, which were then dissolved in 1,4-dioxane and hydrolyzed with $\mathrm{NaOH}$ aqueous solution to obtain picolinic acid analogues 10a-10b. Intermediates $\mathbf{1 0 a - 1 0 b}$ were reacted with $\mathrm{SOCl}_{2}$ to get the corresponding acyl chlorides and then connected with amines (including propan-1-amine, 2-(thiophen-2-yl)ethan-1-amine, pyrrolidine and 3-morpholinopropan-1-amine) to obtain picolinamide analogues 11a-11e. Finally, the key intermediates 12a-12e were produced by the reduction of 11a-11e with hydrazine hydrate as reducing agent. Other intermediates 13a-13i, which have been reported in our previous research [15], were combined with intermediates 12a-12e by a nucleophilic substitute reaction to get the target compounds B1-B27.

The structural information of the target compounds was confirmed by ${ }^{1} \mathrm{H}-\mathrm{NMR},{ }^{13} \mathrm{C}-\mathrm{NMR}$, and TOF MS (ES+), which were consistent with the structures depicted.

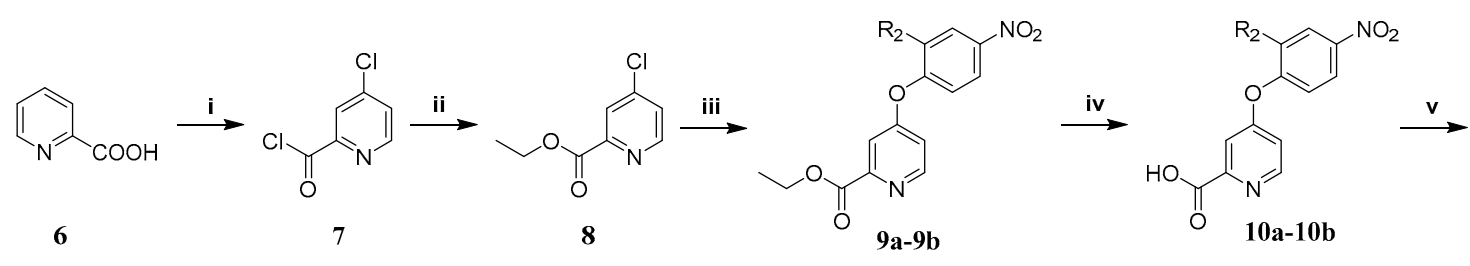<smiles>[R]C(=O)c1cc(Oc2ccc([N+](=O)[O-])cc2[R])ccn1</smiles>

11a-11e

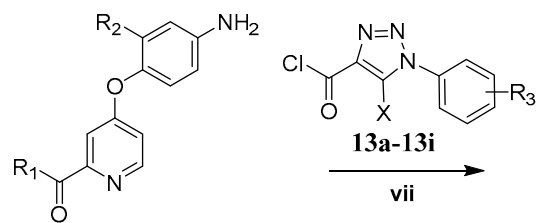

12a-12e

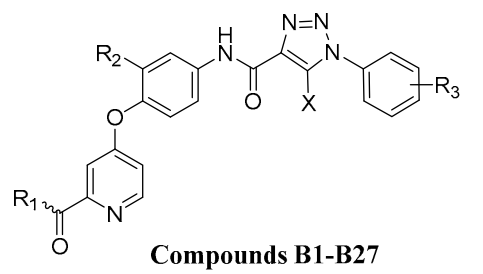

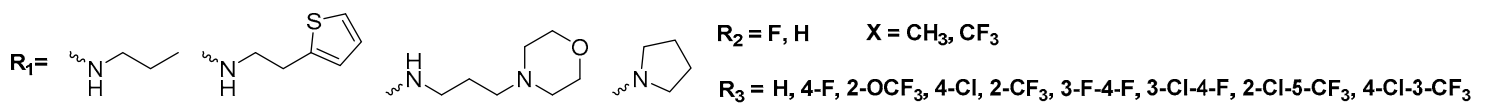

Scheme 1. The synthetic route for target compounds B1-B27. Reagents and conditions: (i) $\mathrm{NaBr}$, $\mathrm{SOCl}_{2}, 85^{\circ} \mathrm{C}, 18 \mathrm{~h}$; (ii) triethylamine, dichloromethane (DCM), EtOH, $0{ }^{\circ} \mathrm{C}, 1 \mathrm{~h}$; (iii) $p$-nitrophenol or 2-fluoro-4-nitrophenol, chlorobenzene, $135^{\circ} \mathrm{C}, 4 \mathrm{~h}$; (iv) 1,4-dioxane, sodium hydroxide (10\%), r.t., $0.5 \mathrm{~h}$; (v) $\mathrm{SOCl}_{2}$, amines, $\mathrm{Et}_{3} \mathrm{~N}, \mathrm{DCM}, 0-85{ }^{\circ} \mathrm{C}$, $1 \mathrm{~h}$; (vi) EtOH, activated carbon, $\mathrm{FeCl}_{3} \cdot 6 \mathrm{H}_{2} \mathrm{O}$, hydrazine hydrate $(80 \%), 90^{\circ} \mathrm{C}, 4 \mathrm{~h}$. (vii) $\mathrm{EtOH}$, activated carbon, $\mathrm{FeCl}_{3} \cdot 6 \mathrm{H}_{2} \mathrm{O}$, hydrazine hydrate $(80 \%), 90{ }^{\circ} \mathrm{C}$, $4 \mathrm{~h}$; (vii) $\mathrm{DCM}, \mathrm{NaHCO}_{3}, 0^{\circ} \mathrm{C}, 1 \mathrm{~h}$.

\subsection{Antitumor Activity of Compounds B1-B27 Against A549, HeLa, and MCF-7 Cell Lines and SAR Analysis}

The antitumor activity of target compounds against A549, HeLa, and MCF-7 cell lines was evaluated to investigate their inhibitory activity against cancer cells [16]. The antitumor activities of compounds were displayed as the $\mathrm{IC}_{50}$ (half-inhibitory concentration) values, as shown in Tables 1 and 2. Most compounds exhibited moderate to potent antitumor activity against three cell lines. Compounds B25-B27 possessed more potent inhibitory activity than Golvatinib, as shown in Table 2, with $\mathrm{IC}_{50}$ values in the range of 3.22-13.60 $\mu \mathrm{M}$. The optimal compound B26 showed excellent inhibitory activity against A549, HeLa, and MCF-7 cell lines with $\mathrm{IC}_{50}$ values of $3.22 \pm 0.12,4.33 \pm 0.09$, and $5.82 \pm 0.09 \mu \mathrm{M}$, respectively, which were more efficient than Golvatinib $(8.14 \pm 0.45,15.17 \pm 0.17$, and $16.91 \pm 0.29 \mu \mathrm{M})$. 
Table 1. Antitumor activities of the target compounds B1-B18 against A549, HeLa, and MCF-7 cell lines.

\begin{tabular}{|c|c|c|c|c|c|c|}
\hline \multirow{2}{*}{ Compd. } & \multirow{2}{*}{$\mathbf{R}_{\mathbf{2}}$} & \multirow{2}{*}{$\mathbf{R}_{3}$} & \multirow{2}{*}{ Z } & \multicolumn{3}{|c|}{$\mathrm{IC}_{50}(\mu \mathrm{M}) \pm \mathrm{SD}$} \\
\hline & & & & A549 & HeLa & MCF-7 \\
\hline B1 & \multirow{9}{*}{$\mathbf{H}$} & $4-\mathrm{H}$ & $\mathrm{CH}_{3}$ & $46.55 \pm 1.90$ & $52.31 \pm 5.42$ & $63.05 \pm 2.44$ \\
\hline B2 & & $4-\mathrm{F}$ & $\mathrm{CH}_{3}$ & $21.30 \pm 0.66$ & $42.06 \pm 6.03$ & $32.13 \pm 0.86$ \\
\hline B3 & & $2-\mathrm{OCF}_{3}$ & $\mathrm{CH}_{3}$ & $32.67 \pm 1.16$ & $53.94 \pm 4.23$ & $48.71 \pm 3.26$ \\
\hline B4 & & $4-\mathrm{Cl}$ & $\mathrm{CF}_{3}$ & $56.26 \pm 2.26$ & $48.23 \pm 1.59$ & $120.76 \pm 1.25$ \\
\hline B5 & & $2-\mathrm{CF}_{3}$ & $\mathrm{CF}_{3}$ & $35.57 \pm 1.03$ & $59.55 \pm 2.94$ & $270.40 \pm 12.35$ \\
\hline B6 & & 3-F-4-F & $\mathrm{CF}_{3}$ & $256.30 \pm 10.37$ & $170.38 \pm 13.69$ & $\mathrm{NA}^{\mathrm{a}}$ \\
\hline B7 & & 3-Cl-4-F & $\mathrm{CF}_{3}$ & $221.98 \pm 21.46$ & $295.65 \pm 15.37$ & NA \\
\hline B8 & & $2-\mathrm{Cl}-5-\mathrm{CF}_{3}$ & $\mathrm{CF}_{3}$ & $238.07 \pm 17.84$ & NA & NA \\
\hline B9 & & $4-\mathrm{Cl}-3-\mathrm{CF}_{3}$ & $\mathrm{CF}_{3}$ & $357.24 \pm 14.50$ & NA & NA \\
\hline B10 & \multirow{9}{*}{ F } & $4-\mathrm{H}$ & $\mathrm{CH}_{3}$ & $33.31 \pm 1.25$ & $41.55 \pm 2.26$ & $60.50 \pm 3.99$ \\
\hline B11 & & $4-\mathrm{F}$ & $\mathrm{CH}_{3}$ & $19.70 \pm 0.89$ & $46.57 \pm 1.59$ & $29.11 \pm 1.30$ \\
\hline B12 & & $2-\mathrm{OCF}_{3}$ & $\mathrm{CH}_{3}$ & $24.24 \pm 0.71$ & $53.04 \pm 1.11$ & $42.26 \pm 1.09$ \\
\hline B13 & & $4-\mathrm{Cl}$ & $\mathrm{CF}_{3}$ & $46.13 \pm 3.59$ & $55.43 \pm 2.30$ & $82.48 \pm 2.34$ \\
\hline B14 & & $2-\mathrm{CF}_{3}$ & $\mathrm{CF}_{3}$ & $32.94 \pm 2.33$ & $40.68 \pm 1.09$ & $84.45 \pm 12.34$ \\
\hline B15 & & 3-F-4-F & $\mathrm{CF}_{3}$ & $123.07 \pm 10.23$ & $240.60 \pm 22.49$ & $332.01 \pm 20.08$ \\
\hline B16 & & $3-\mathrm{Cl}-4-\mathrm{F}$ & $\mathrm{CF}_{3}$ & $150.58 \pm 12.21$ & $270.24 \pm 13.56$ & NA \\
\hline B17 & & $2-\mathrm{Cl}-5-\mathrm{CF}_{3}$ & $\mathrm{CF}_{3}$ & $223.34 \pm 10.89$ & NA & NA \\
\hline B18 & & $4-\mathrm{Cl}-3-\mathrm{CF}_{3}$ & $\mathrm{CF}_{3}$ & $246.70 \pm 21.23$ & NA & NA \\
\hline \multicolumn{2}{|c|}{ Golvatinib $^{b}$} & & & $8.14 \pm 0.45$ & $15.17 \pm 0.17$ & $16.91 \pm 0.29$ \\
\hline
\end{tabular}

a NA: Low inhibitory activity, ${ }^{\mathrm{b}}$ Used as the positive control.

Table 2. Antitumor activities of the target compounds B10-B12 and B19-B27 against A549, HeLa, and MCF-7 cell lines.

\begin{tabular}{|c|c|c|c|c|c|}
\hline \multirow{2}{*}{ Compd. } & \multirow{2}{*}{$\mathbf{R}_{1}$} & \multirow{2}{*}{$\mathbf{R}_{3}$} & \multicolumn{3}{|c|}{$\mathrm{IC}_{50}(\mu \mathrm{M}) \pm \mathrm{SD}$} \\
\hline & & & A549 & HeLa & MCF-7 \\
\hline B10 & \multirow{3}{*}{$\sum_{-2}^{H}{ }_{-1}^{H}$} & $4-\mathrm{H}$ & $33.31 \pm 1.25$ & $41.55 \pm 2.26$ & $60.50 \pm 3.99$ \\
\hline B11 & & 4-F & $19.70 \pm 0.89$ & $46.57 \pm 1.59$ & $29.11 \pm 1.30$ \\
\hline B12 & & $2-\mathrm{OCF}_{3}$ & $24.24 \pm 0.71$ & $53.04 \pm 1.11$ & $42.26 \pm 1.09$ \\
\hline B19 & \multirow{3}{*}{$\left.\xi_{-2} \mathrm{~N}\right\rangle$} & 4-H & $27.25 \pm 0.79$ & $32.31 \pm 2.11$ & $39.08 \pm 0.97$ \\
\hline B20 & & 4-F & $12.10 \pm 0.31$ & $21.84 \pm 1.93$ & $19.12 \pm 0.21$ \\
\hline B21 & & $2-\mathrm{OCF}_{3}$ & $17.72 \pm 0.42$ & $29.55 \pm 2.04$ & $41.10 \pm 1.21$ \\
\hline B22 & \multirow{3}{*}{$\xi^{H} \mathbb{N}^{\mathrm{N}}$} & $4-\mathrm{H}$ & $19.88 \pm 0.75$ & $45.18 \pm 3.89$ & $33.80 \pm 1.11$ \\
\hline B23 & & 4-F & $12.52 \pm 0.37$ & $15.19 \pm 0.96^{\mathrm{a}}$ & $35.11 \pm 3.05$ \\
\hline B24 & & $2-\mathrm{OCF}_{3}$ & $13.34 \pm 0.58$ & $19.73 \pm 0.83$ & $44.82 \pm 2.96$ \\
\hline B25 & \multirow{3}{*}{ 婴 } & $4-\mathrm{H}$ & $6.43 \pm 0.21$ & $10.51 \pm 0.68$ & $13.60 \pm 0.86$ \\
\hline B26 & & 4-F & $3.22 \pm 0.12$ & $4.33 \pm 0.09$ & $5.82 \pm 0.09$ \\
\hline B27 & & $2-\mathrm{OCF}_{3}$ & $4.91 \pm 0.09$ & $5.72 \pm 0.17$ & $9.34 \pm 0.52$ \\
\hline Golvatoini & & & $8.14 \pm 0.45$ & $15.17 \pm 0.17$ & $16.91 \pm 0.29$ \\
\hline
\end{tabular}

a Bold values show the $\mathrm{IC}_{50}$ values of the target compounds lower than the values of the positive control; ${ }^{\mathrm{b}}$ Used as the positive control. 
According to the antitumor activity of compounds B1-B27 listed in Tables 1 and 2, the SARs were summarized as follows. Overall, the $\mathrm{F}$ atom on the meta-central benzene ring provided stronger inhibitory activity against cancer cells than $\mathrm{H}$ atom, for example, compounds B1-B8 displayed less inhibitory activity than compounds B9-B18. A single substitution (such as $\mathrm{H} / \mathrm{F} / \mathrm{OCF} / \mathrm{Cl}_{3} / \mathrm{CF}_{3}$ ) linked to the terminal benzene ring was favorable for maintaining the biological activity, such as compounds B1-B5 and B10-B15 that possessed moderate antitumor activity with $\mathrm{IC}_{50}$ values less than $60 \mu \mathrm{M}$ against A549 and HeLa cell lines. However, the double substituents connected to the terminal benzene ring obviously impaired the inhibitory activity of compounds B6-B9 and B15-B18, whose $\mathrm{IC}_{50}$ values were more than $120 \mu \mathrm{M}$ against three cell lines. A possible explanation would be that the introduction of two substituents to the terminal benzene ring may create steric hindrance, which made it difficult for compounds to extend into the hydrophobic pocket and to bind tightly to c-Met kinase.

Inspired by the inhibitory activity of compounds B1-B3 and B10-B12, as shown in Table 1, the F atom of the central benzene ring and the single group $\left(\mathrm{H}, \mathrm{F}\right.$, or $\left.\mathrm{OCF}_{3}\right)$ of the terminal benzene ring were reserved to perform a SAR study of the pyridine amide moiety. Hydrophilic groups, including morpholine or thiophene groups attached to the terminal of pyridine amide, have a great contribution to inhibitory activity of the compounds B22-B27 (with $\mathrm{IC}_{50}$ values in the range of 3.22-45.18 $\mu \mathrm{M}$ ).

In summary, introducing morpholino groups and $\mathrm{F}$ atoms to the pyridylpropyl amide and the terminal benzene ring, respectively, made significant advances in the inhibitory activity.

\subsection{Dose-Dependent Test of Compound B26 Against A549 Cells}

To explore the relationship between concentrations and antitumor activity of compound B26, we carried out a dose-dependent test based on the MTT method [16], in which A549 cells were treated with seven different concentrations of compound B26 $(0.137,0.411,1.234,3.704,11.11,33.33$, and $100 \mu \mathrm{M})$, using Golvatinib as a positive control, as seen in Figure 3. The results revealed that compound B26 could effectively inhibit cancer cells in a dose-dependent manner. Notably, compound B26 inhibited A549 cells more than $50 \%$ at the concentration of $3.704 \mu \mathrm{M}$, while the inhibitory rate of Golvatinib was less than $40 \%$ at the same concentration.

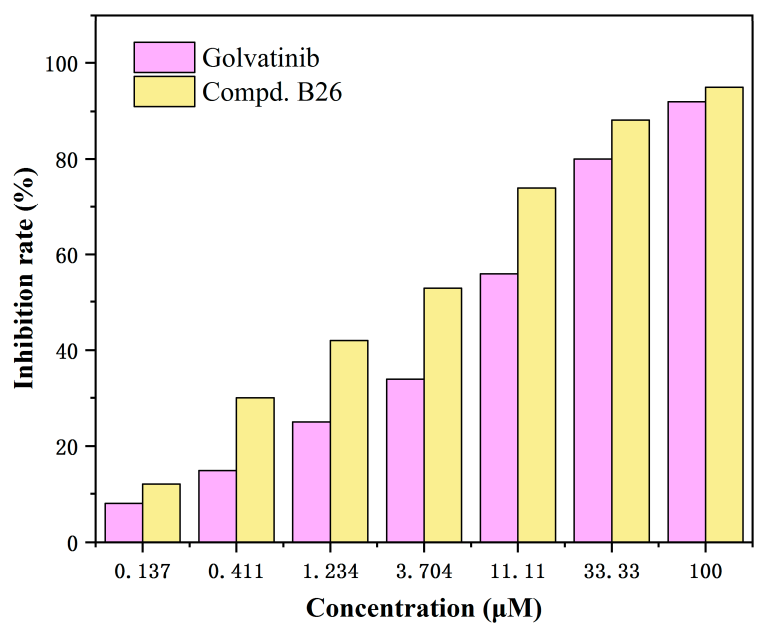

Figure 3. Relationship between concentration and inhibition rate of compound B26 against A549 cells.

\subsection{Cell Cycle Study of A549 Cells Treated with Compound B26}

To further investigate the inhibitory pattern of compound B26 on the growth of cancer cells, cell cycle distribution analysis [17] was carried out on A549 cells, as shown in Figure 4. Compound B26 at concentrations of 5,10 , and $15 \mu \mathrm{M}$ and Golvatinib at a concentration of $5 \mu \mathrm{M}$ were delivered to A549 cells for $24 \mathrm{~h}$, as shown in Figure 4. With the increased concentration of compound B26, the percentage of cells blocked in $\mathrm{G}_{0} / \mathrm{G}_{1}$ phase was increased from $65.44 \%$ to $79.18 \%$, while the percentage in the $\mathrm{S}$ phase decreased from $21.91 \%$ to $16.56 \%$. There was no significant change in $\mathrm{G}_{2} / \mathrm{M}$ phase. The result 
showed that compound B26 (74.41\%) and Golvatinib (74.77\%) had the same inhibitory effect on A549 cells at the concentration of $5 \mu \mathrm{M}$, both of which could block cells in the $G_{0} / G_{1}$ phase.
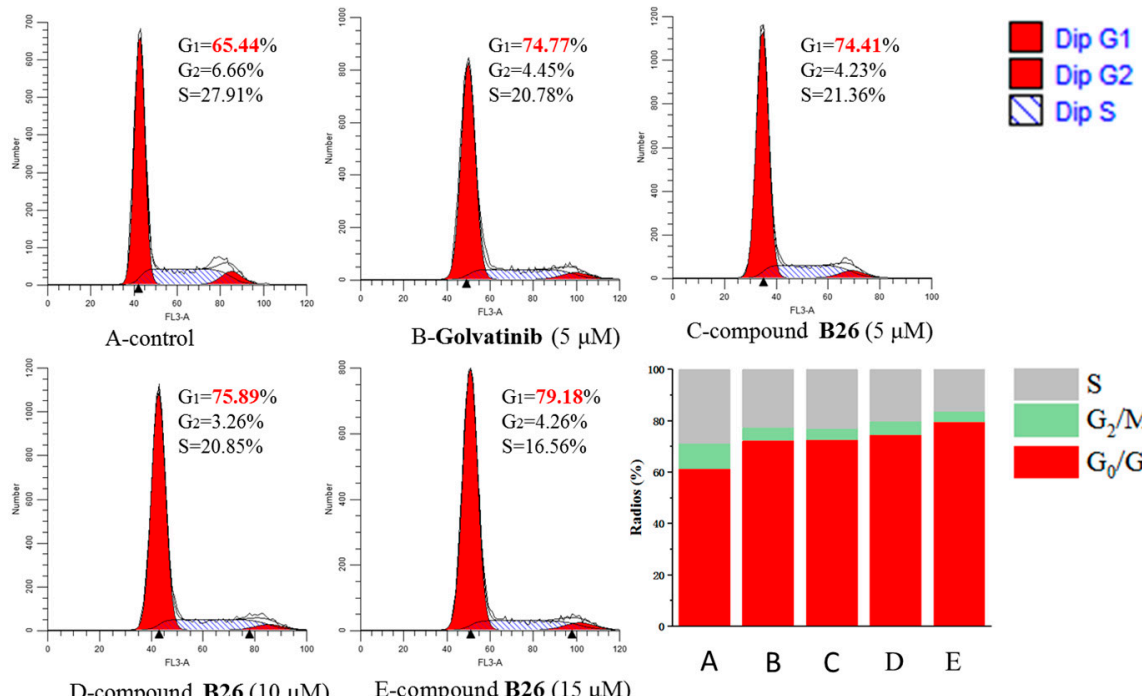

Figure 4. Cell cycle study of A549 cells treated with compound B26 and Golvatinib.

\section{5. c-Met Enzyme Assay of Compounds B25-B27 and Staurosporine}

Compounds B25, B26, and B27, possessing potent antitumor activity against A549, HeLa, and MCF-7 cell lines, were selected to investigate their c-Met kinase assay by mobility shift assay method [18] with staurosporine as a positive control, which was used to insure the reliability of the experimental data. Compound B26 exhibited potent inhibitory activity against c-Met with an inhibition rate of $36 \%$ at the concentration of $0.625 \mu \mathrm{M}$, as shown in Table 3 .

Table 3. c-Met kinase activity of selected compounds B25, B26, B27, and staurosporine.

\begin{tabular}{cc}
\hline Compound $(\mathbf{0 . 6 2 5} \boldsymbol{\mu M})$ & Rates (\%) \\
\hline B25 & 4.3 \\
B26 & 36.0 \\
B27 & 23.8 \\
Staurosporine & 87.3 \\
\hline
\end{tabular}

\subsection{Molecular Docking Simulation of Compounds (B26 and Golvatinib) and c-Met}

Next, we further explored the binding mode of compound B26 and Golvatinib with c-Met kinase (PDB: 3LQ8, extracted from the PDB database) through molecule docking simulation using AutoDock 4.2 software [19], as shown in Figure 5. The docking results indicated that compound B26 and Golvatinib in an extended conformation formed strong hydrogen bonding interactions with residues Met1160, Asp1222, and Lys1110, as shown in Figure 5a-d. Interestingly, the pyridylamide structure of compound B26 formed a bidentate hydrogen bond with residue Met1160, as shown in Figure 5a,b, which may offer a stronger ability of compound B26 to bind with c-Met. Compound B26 formed more hydrogen bonding interactions with Met1160 than Golvatinib, which may explain the better antitumor activity of compound B26. 

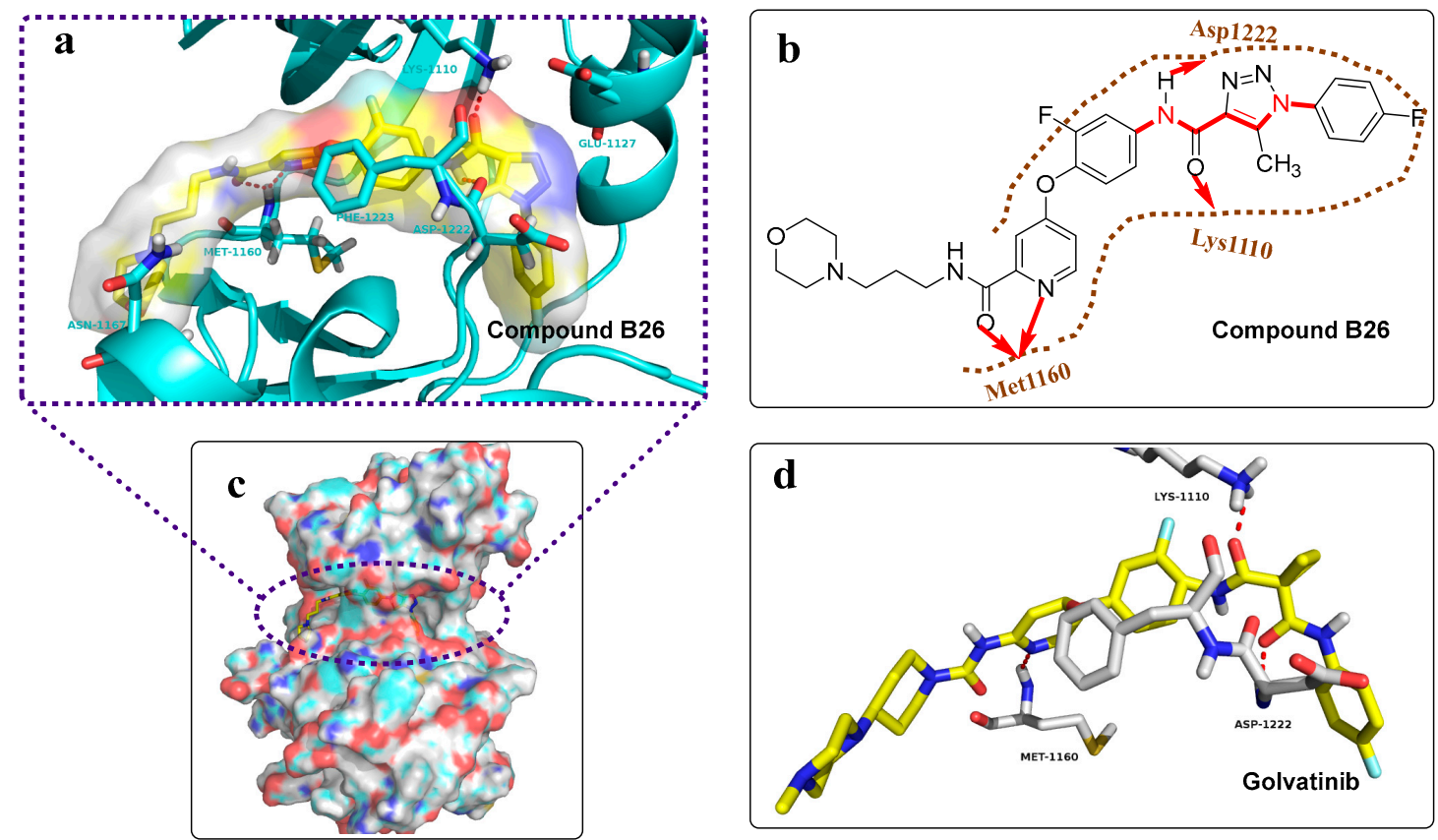

Figure 5. Figure $5 a, 5 b$, and $5 c$ are partial views, two-dimensional partial views, and integral cavity views of the docking results of c-Met (PDB code: 3LQ8) and compound B26, respectively. Figure 5d shows partial views of c-Met and Golvatinib. The c-Met protein and compounds are displayed by cartoons and sticks, respectively. Hydrogen bonding interactions between compounds and c-Met are indicated with dashed lines or arrows in red.

\section{Experimental Section}

\subsection{Chemistry}

Unless specifically required, all reagents used in the experiments were purchased as commercial analytical grade and used without further purification. Frequently used solvents (dichloromethane, ethyl acetate, tetrahydrofuran, 1,4-dioxane, methanol, ethanol, etc.) were absolutely anhydrous. Flash column chromatography was performed on silica gel (300 mesh) using a mixture of petroleum ether (PE) and ethyl acetate (EA). The reaction process was monitored by thin-layer chromatography (TLC, SH-GH254) and spots were visualized with ultraviolet analyzer (light in 254 or $365 \mathrm{~nm}$ ). ${ }^{1} \mathrm{H}-\mathrm{NMR}$ and ${ }^{13} \mathrm{C}$-NMR spectra analysis of compounds was implemented in Bruker $400 \mathrm{MHz}$ spectrometer (Bruker Bioscience, Billerica, MA, USA) using tetramethylsilane (TMS) as an internal standard at room temperature. Mass spectrometry (MS) of target compounds was carried out Waters High Resolution Quadrupole Time of Flight Tandem Mass Spectrometry (Waters, Xevo G2-XS Tof). The melting point of the compounds was measured by SGW X-4 micro melting point instrument. The purity of compounds was determined by an Agilent 1260 liquid chromatograph equipped with an Inertex-C18 column, and all were more than $95 \%$.

\subsubsection{Preparation of 4-Chloropicolinoyl Chloride (7)}

Pyridinecarboxylic acid 6 (10.00 g, $0.081 \mathrm{~mol}), \mathrm{NaBr}(0.10 \mathrm{~g}, 0.001 \mathrm{~mol})$, and a drop of $\mathrm{N}, \mathrm{N}$-dimethylformamide (DMF) were added in thionyl chloride $\left(\mathrm{SOCl}_{2}, 50 \mathrm{~mL}\right)$ and stirred at $85^{\circ} \mathrm{C}$ for $18 \mathrm{~h}$. The reaction was monitored by TLC. After completion of the reaction, the solvent was removed under vacuum to obtain a yellow liquid, which was dissolved in DCM for further use.

\subsubsection{Preparation of Ethyl 4-Chloropicolinate (8)}

Dichloromethane $(30 \mathrm{~mL})$, ethanol $(16.43 \mathrm{~g}, 0.170 \mathrm{~mol})$, and triethylamine $(17.17 \mathrm{~g}, 0.170 \mathrm{~mol})$ were successively added to a beaker and stirred at $0{ }^{\circ} \mathrm{C}$ for $0.5 \mathrm{~h}$. Subsequently, a mixture of 
4-chloropicolinoyl chloride 7 (16.43 g, $0.110 \mathrm{~mol})$ and DCM $(5 \mathrm{~mL})$ was added dropwise, stirred at $0{ }^{\circ} \mathrm{C}$ for $0.5 \mathrm{~h}$, and monitored by TLC. After completion of the reaction, $\mathrm{NaOH}$ solution was added to the mixture to adjust the $\mathrm{pH}$ value 9-10. Ultimately, the organic layers were combined and dried to obtain a brown liquid.

3.1.3. Preparation of Ethyl 4-(4-Nitrophenoxy)picolinate (9a) and Ethyl4-(2-Fluoro-4-Nitrophenoxy) picolinate $(9 b)$

Intermediate 8 (13.22 $\mathrm{g}, 0.071 \mathrm{~mol})$ and $p$-nitrophenol or 2-fluoro-4-nitrophenol $(0.026 \mathrm{~mol})$ were dissolved in chlorobenzene $(40 \mathrm{~mL})$ and then stirred at $130{ }^{\circ} \mathrm{C}$ for $4 \mathrm{~h}$. The completion of the reaction was monitored by TLC. After completion of the reaction, the cold petroleum ether $(100 \mathrm{~mL})$ was poured into the reaction solvent and stirred at room temperature for $0.5 \mathrm{~h}$. Next, petroleum ether $(100 \mathrm{~mL}) \mathrm{was}$ poured off to give a viscous liquid, which was then dissolved in DCM (300 mL) and extracted with aqueous solution of $\mathrm{NaOH}$. The organic layer was combined, dried, and concentrated under vacuum to get a pale yellow solid.

3.1.4. Preparation of 4-(4-Nitrophenoxy)picolinic Acid (10a) and 4-(2-Fluoro-4-Nitrophenoxy)picolinic Acid (10b)

Intermediates $\mathbf{9 a - 9 b}(0.035 \mathrm{~mol})$ were dissolved in 1,4-dioxane $(50 \mathrm{~mL})$ and stirred at room temperature for $0.5 \mathrm{~h}$. A solution of $10 \% \mathrm{NaOH}(2.28 \mathrm{~mL}, 0.057 \mathrm{~mol})$ was then added dropwise to the above mixture, stirred at room temperature for $0.5 \mathrm{~h}$, and monitored by TLC. After completion of the reaction, the solvent was evaporated under vacuum to give a white solid. The white solid was then dissolved in saturated $\mathrm{NaCl}$ solution $(500 \mathrm{~mL})$ and stirred at room temperature for $10 \mathrm{~h}$. Subsequently, after the $\mathrm{pH}$ of the solution was adjusted to $2-3$ by $75 \%$ hydrochloric acid ( $\mathrm{HCl})$, a yellow solid was precipitated, filtered, and dried.

3.1.5. Preparation of 4-(4-Nitrophenoxy)picolinamide or 4-(2-Fluoro-4-Nitrophenoxy)picolinamide Analogues (11a-11e)

Intermediates 10a-10b $(0.020 \mathrm{~mol})$ and one drop of DMF were successively dissolved in $\mathrm{SOCl}_{2}$ $(50 \mathrm{~mL})$ and stirred at $85{ }^{\circ} \mathrm{C}$ for $0.5 \mathrm{~h}$. Then reaction solvent was concentrated in vacuum, dissolved in DCM (8 mL), and added dropwise to a mixture of DCM (50 mL), ammonia analogs $(0.020 \mathrm{~mol})$, and triethylamine $(0.020 \mathrm{~mol})$. The reaction solution was stirred at $0{ }^{\circ} \mathrm{C}$ for $0.5 \mathrm{~h}$, and monitored by TLC. Finally, a gray slid was obtained by the same post-treatment method as that used for preparation of ethyl 4-chloropicolinate 8.

3.1.6. Preparation of 4-(4-Aminophenoxy)picolinamide or 4-(2-Fluoro-4-aminophenoxy)picolinamide Analogues (12a-12e)

Intermediates 11a-11e $(0.016 \mathrm{~mol})$, activated carbon $(1.92 \mathrm{~g}, 0.160 \mathrm{~mol})$, and $\mathrm{FeCl}_{3} \cdot 6 \mathrm{H}_{2} \mathrm{O}(0.43 \mathrm{~g}$, $0.016 \mathrm{~mol})$ were dissolved in ethanol $(30 \mathrm{~mL})$ and stirred at $90{ }^{\circ} \mathrm{C}$ for $0.5 \mathrm{~h}$. Then, $80 \%$ hydrazine hydrate $(8.00 \mathrm{~g}, 0.128 \mathrm{~mol})$ was added dropwise and stirred for $3.5 \mathrm{~h}$. The reaction was monitored by TLC. After completion of the reaction, the solution was filtered, concentrated, and recrystallized to give a green solid.

3.1.7. Preparation of 5-Methyl-1-Phenyl-1H-1,2,3-Triazole-4-Carbonyl Chloride or 1-Phenyl-5(trifluoromethyl)-1H-1,2,3-Triazole-4-Carbonyl Chloride Analogues (13i-13e)

The preparation of intermediates 13a-13i was carried out according to our previous research [15].

\subsubsection{Preparation of Target Compounds B1-B27}

Intermediates 12a-12e $(0.002 \mathrm{~mol})$ and sodium bicarbonate $(4.20 \mathrm{~g}, 0.005 \mathrm{~mol})$ were dissolved in DCM and stirred at $0{ }^{\circ} \mathrm{C}$ for $0.5 \mathrm{~h}$. The solution of intermediates $13 \mathbf{a}-13 \mathbf{i}(0.002 \mathrm{~mol})$ and DCM were added dropwise to the above mixture, and stirred at $0{ }^{\circ} \mathrm{C}$ for $0.5 \mathrm{~h}$. The reaction was monitored 
by TLC. After completion of the reaction, the solution was extracted with a mixture of DCM/NaOH $(500 \mathrm{~mL})$ three times and then the organic layers were combined, dried over sodium sulfate, evaporated, and purified by chromatographic column to possess a light yellow or white solid.

4-(4-(5-methyl-1-phenyl-1H-1,2,3-triazole-4-carboxamido)phenoxy)-N-propylpicolinamide (B1) Light yellow solid; Yield: 78.5\%; m.p.: $116.8-117.1{ }^{\circ} \mathrm{C} ;{ }^{1} \mathrm{H}-\mathrm{NMR}\left(400 \mathrm{MHz}, \mathrm{DMSO}-d_{6}, \mathrm{ppm}\right) \delta 10.75$ (s, $\left.1 \mathrm{H}\right), 8.82(\mathrm{~s}$, $1 \mathrm{H}), 8.52(\mathrm{~d}, J=5.5 \mathrm{~Hz}, 1 \mathrm{H}), 8.03(\mathrm{~s}, 1 \mathrm{H}), 8.01(\mathrm{~s}, 1 \mathrm{H}), 7.67(\mathrm{~s}, 2 \mathrm{H}), 7.64(\mathrm{~d}, J=6.4 \mathrm{~Hz}, 2 \mathrm{H}), 7.43(\mathrm{~s}, 1 \mathrm{H})$, $7.23(\mathrm{~d}, J=8.4 \mathrm{~Hz}, 2 \mathrm{H}), 7.18(\mathrm{~d}, J=4.5 \mathrm{~Hz}, 1 \mathrm{H}), 3.22(\mathrm{dd}, J=12.8,6.3 \mathrm{~Hz}, 2 \mathrm{H}), 2.59(\mathrm{~s}, 3 \mathrm{H}), 1.50(\mathrm{dt}$, $J=14.1,7.0 \mathrm{~Hz}, 2 \mathrm{H}), 0.84(\mathrm{t}, J=7.2 \mathrm{~Hz}, 3 \mathrm{H})$. TOF MS ES+ $(\mathrm{m} / z):[\mathrm{M}+\mathrm{H}]^{+}$, calcd for $\mathrm{C}_{25} \mathrm{H}_{24} \mathrm{~N}_{6} \mathrm{O}_{3}$ : 457.1988 , found, 457.1986 .

4-(4-(1-(4-fluorophenyl)-5-methyl-1H-1,2,3-triazole-4-carboxamido)phenoxy)-N-propylpicolinamide (B2) Light yellow solid; Yield: 59.3\%; m.p.: $110.4-110.8{ }^{\circ} \mathrm{C} ;{ }^{1} \mathrm{H}-\mathrm{NMR}\left(400 \mathrm{MHz}, \mathrm{DMSO}-d_{6}, \mathrm{ppm}\right) \delta 10.64(\mathrm{~s}, 1 \mathrm{H})$, $8.71(\mathrm{~s}, 1 \mathrm{H}), 8.40(\mathrm{~d}, J=5.6 \mathrm{~Hz}, 1 \mathrm{H}), 7.91(\mathrm{~s}, 1 \mathrm{H}), 7.89(\mathrm{~s}, 1 \mathrm{H}), 7.65(\mathrm{~d}, J=4.8 \mathrm{~Hz}, 1 \mathrm{H}), 7.63(\mathrm{~d}, J=4.6 \mathrm{~Hz}$, $1 \mathrm{H}), 7.39(\mathrm{t}, J=8.7 \mathrm{~Hz}, 2 \mathrm{H}), 7.31(\mathrm{~d}, J=2.1 \mathrm{~Hz}, 1 \mathrm{H}), 7.11(\mathrm{~d}, J=8.8 \mathrm{~Hz}, 2 \mathrm{H}), 7.06(\mathrm{~d}, J=3.1 \mathrm{~Hz}, 1 \mathrm{H}), 3.10$ $(\mathrm{dd}, J=13.3,6.6 \mathrm{~Hz}, 2 \mathrm{H}), 2.46(\mathrm{~s}, 3 \mathrm{H}), 1.38(\mathrm{dt}, J=14.2,7.1 \mathrm{~Hz}, 2 \mathrm{H}), 0.72(\mathrm{t}, J=7.3 \mathrm{~Hz}, 3 \mathrm{H})$. TOF MS ES+ $(m / z):[\mathrm{M}+\mathrm{H}]^{+}$, calcd for $\mathrm{C}_{25} \mathrm{H}_{23} \mathrm{FN}_{6} \mathrm{O}_{3}: 475.1894$, found, 475.1896 .

4-(4-(5-methyl-1-(2-(trifluoromethoxy)phenyl)-1H-1,2,3-triazole-4-carboxamido)phenoxy)-N-propylpicolinamide (B3) White solid; Yield: 78.2\%; m.p.: 97.7-98.0 ${ }^{\circ} \mathrm{C} ;{ }^{1} \mathrm{H}-\mathrm{NMR}\left(400 \mathrm{MHz}, \mathrm{DMSO}-d_{6}, \mathrm{ppm}\right) \delta 10.81$ (s, $1 \mathrm{H}), 8.81(\mathrm{~s}, 1 \mathrm{H}), 8.52(\mathrm{~d}, J=5.3 \mathrm{~Hz}, 1 \mathrm{H}), 8.03(\mathrm{~s}, 1 \mathrm{H}), 8.01(\mathrm{~s}, 1 \mathrm{H}), 7.88(\mathrm{~d}, J=7.7 \mathrm{~Hz}, 1 \mathrm{H}), 7.84(\mathrm{~d}$, $J=7.6 \mathrm{~Hz}, 1 \mathrm{H}), 7.78(\mathrm{~d}, J=7.7 \mathrm{~Hz}, 1 \mathrm{H}), 7.72(\mathrm{t}, J=7.2 \mathrm{~Hz}, 1 \mathrm{H}), 7.42(\mathrm{~s}, 1 \mathrm{H}), 7.23(\mathrm{~d}, J=8.6 \mathrm{~Hz}, 2 \mathrm{H}), 7.18$ $(\mathrm{d}, J=0.8 \mathrm{~Hz}, 1 \mathrm{H}), 3.22(\mathrm{~d}, J=6.2 \mathrm{~Hz}, 2 \mathrm{H}), 2.46(\mathrm{~s}, 3 \mathrm{H}), 1.51(\mathrm{dd}, J=14.0,7.0 \mathrm{~Hz}, 2 \mathrm{H}), 0.84(\mathrm{t}, J=7.2 \mathrm{~Hz}$, $3 \mathrm{H})$. TOF MS ES+ (m/z): $[\mathrm{M}+\mathrm{H}]^{+}$, calcd for $\mathrm{C}_{26} \mathrm{H}_{23} \mathrm{~F}_{3} \mathrm{~N}_{6} \mathrm{O}_{4}: 541.1811$, found, 541.1813 .

4-(4-(1-(4-chlorophenyl)-5-(trifluoromethyl)-1H-1,2,3-triazole-4-carboxamido)phenoxy)-N-propylpicolinamide (B4) White solid; Yield: 66.4\%; m.p.: $159.0-159.2{ }^{\circ} \mathrm{C} ;{ }^{1} \mathrm{H}-\mathrm{NMR}$ (400 MHz, DMSO-d 6 , ppm) $\delta 11.19$ $(\mathrm{s}, 1 \mathrm{H}), 8.80(\mathrm{~s}, 1 \mathrm{H}), 8.52(\mathrm{~d}, J=5.5 \mathrm{~Hz}, 1 \mathrm{H}), 7.99(\mathrm{~s}, 1 \mathrm{H}), 7.97(\mathrm{~d}, J=1.2 \mathrm{~Hz}, 1 \mathrm{H}), 7.79(\mathrm{~d}, J=4.4 \mathrm{~Hz}$, $3 \mathrm{H}), 7.75(\mathrm{~d}, J=8.7 \mathrm{~Hz}, 1 \mathrm{H}), 7.42(\mathrm{~s}, 1 \mathrm{H}), 7.27(\mathrm{~d}, J=8.7 \mathrm{~Hz}, 2 \mathrm{H}), 7.19(\mathrm{~d}, J=5.5 \mathrm{~Hz}, 1 \mathrm{H}), 3.23(\mathrm{dd}$, $J=13.2,6.7 \mathrm{~Hz}, 2 \mathrm{H}), 1.57-1.47(\mathrm{~m}, 2 \mathrm{H}), 0.84(\mathrm{t}, J=7.4 \mathrm{~Hz}, 3 \mathrm{H}) .{ }^{13} \mathrm{C}-\mathrm{NMR}\left(100 \mathrm{MHz}, \mathrm{DMSO}-d_{6}, \mathrm{ppm}\right) \delta$ $165.73,163.13,156.58,152.54,150.36(2, C), 149.46,142.31,136.19,135.84,134.09,129.70(2, C), 128.22(2, C)$, 122.40(2,C), 121.33(2,C), 114.18(2,C), 108.95, 40.58, 22.34, 11.27. TOF MS ES+ (m/z): $[\mathrm{M}+\mathrm{H}]^{+}$, calcd for $\mathrm{C}_{25} \mathrm{H}_{20} \mathrm{ClF}_{3} \mathrm{~N}_{6} \mathrm{O}_{3}: 545.1316$, found, 545.1317.

N-propyl-4-(4-(5-(trifluoromethyl)-1-(2-(trifluoromethyl)phenyl)-1H-1,2,3-triazole-4-carboxamido)phenoxy) picolinamide (B5) White yellow solid; Yield: 69.4\%; m.p.: $163.4-163.7{ }^{\circ} \mathrm{C} ;{ }^{1} \mathrm{H}-\mathrm{NMR}\left(400 \mathrm{MHz}, \mathrm{DMSO}-d_{6}\right.$, ppm) $\delta 11.26(\mathrm{~s}, 1 \mathrm{H}), 8.80(\mathrm{~s}, 1 \mathrm{H}), 8.53(\mathrm{~d}, J=5.2 \mathrm{~Hz}, 1 \mathrm{H}), 8.15-8.09(\mathrm{~m}, 2 \mathrm{H}), 8.05(\mathrm{~d}, J=7.2 \mathrm{~Hz}, 1 \mathrm{H}), 8.00$ $(\mathrm{d}, J=7.7 \mathrm{~Hz}, 3 \mathrm{H}), 7.43(\mathrm{~s}, 1 \mathrm{H}), 7.27(\mathrm{~d}, J=8.5 \mathrm{~Hz}, 2 \mathrm{H}), 7.18(\mathrm{~d}, J=2.7 \mathrm{~Hz}, 1 \mathrm{H}), 3.23(\mathrm{dd}, J=12.4$, $6.0 \mathrm{~Hz}, 2 \mathrm{H}), 1.57-1.47(\mathrm{~m}, 2 \mathrm{H}), 0.84(\mathrm{t}, J=7.3 \mathrm{~Hz}, 3 \mathrm{H}) .{ }^{13} \mathrm{C}-\mathrm{NMR}\left(100 \mathrm{MHz}, \mathrm{DMSO}-d_{6}, \mathrm{ppm}\right) \delta 165.72$, $163.14,156.20,152.53,150.36(2, \mathrm{C}), 149.53,141.89,135.72,134.28(2, \mathrm{C}), 132.86,132.02,130.02(2, \mathrm{C}), 127.71$, 122.60(2,C), 121.29(2,C), 114.17(2,C), 108.96, 40.57, 22.33, 11.24. TOF MS ES+ (m/z): $[\mathrm{M}+\mathrm{H}]^{+}$, calcd for $\mathrm{C}_{26} \mathrm{H}_{20} \mathrm{~F}_{6} \mathrm{~N}_{6} \mathrm{O}_{3}$ : 579.1580, found, 579.1573.

4-(4-(1-(3,4-difluorophenyl)-5-(trifluoromethyl)-1H-1,2,3-triazole-4-carboxamido)phenoxy)-N-propylpicolinamide (B6) Light yellow solid; Yield: 85.0\%; m.p.: 97.6-97.8 ${ }^{\circ} \mathrm{C} ;{ }^{1} \mathrm{H}-\mathrm{NMR}$ (400 MHz, DMSO- $d_{6}$, ppm) $\delta 11.21$ $(\mathrm{s}, 1 \mathrm{H}), 8.80(\mathrm{~s}, 1 \mathrm{H}), 8.52(\mathrm{~d}, J=4.9 \mathrm{~Hz}, 1 \mathrm{H}), 8.12(\mathrm{~s}, 1 \mathrm{H}), 7.98(\mathrm{~d}, J=6.9 \mathrm{~Hz}, 2 \mathrm{H}), 7.81(\mathrm{~d}, J=8.9 \mathrm{~Hz}$, $1 \mathrm{H}), 7.74(\mathrm{~s}, 1 \mathrm{H}), 7.41(\mathrm{~s}, 1 \mathrm{H}), 7.27(\mathrm{~d}, J=6.9 \mathrm{~Hz}, 2 \mathrm{H}), 7.20(\mathrm{~d}, J=2.3 \mathrm{~Hz}, 1 \mathrm{H}), 3.26-3.19(\mathrm{~m}, 2 \mathrm{H}), 1.52$ $(\mathrm{dd}, J=13.7,6.8 \mathrm{~Hz}, 2 \mathrm{H}), 0.84(\mathrm{t}, J=7.1 \mathrm{~Hz}, 3 \mathrm{H}) .{ }^{13} \mathrm{C}-\mathrm{NMR}\left(100 \mathrm{MHz}, \mathrm{DMSO}-d_{6}, \mathrm{ppm}\right) \delta 165.73$, $163.13,156.48,152.54,150.36(2, C), 149.48,142.09,135.81,131.59,124.44,122.46(2, C), 121.32(2, C), 118.63$, $118.44,117.06,116.86,114.19(2, \mathrm{C}), 108.93,40.58,22.34,11.26$. TOF MS ES+ (m/z): $[\mathrm{M}+\mathrm{H}]^{+}$, calcd for $\mathrm{C}_{25} \mathrm{H}_{19} \mathrm{~F}_{5} \mathrm{~N}_{6} \mathrm{O}_{3}:$ 547.1517, found, 547.1517.

4-(4-(1-(3-chloro-4-fluorophenyl)-5-(trifluoromethyl)-1H-1,2,3-triazole-4-carboxamido)phenoxy)-N-propylpicolinamide (B7) White solid; Yield: 81.6\%; m.p.: 153.6-153.9 ${ }^{\circ} \mathrm{C} ;{ }^{1} \mathrm{H}-\mathrm{NMR}\left(400 \mathrm{MHz}, \mathrm{DMSO}-d_{6}\right.$, ppm) $\delta 11.23$ (s, 
$1 \mathrm{H}), 8.80(\mathrm{t}, J=5.9 \mathrm{~Hz}, 1 \mathrm{H}), 8.52(\mathrm{~d}, J=5.6 \mathrm{~Hz}, 1 \mathrm{H}), 7.99(\mathrm{~s}, 1 \mathrm{H}), 7.97(\mathrm{~s}, 1 \mathrm{H}), 7.79(\mathrm{~d}, J=4.0 \mathrm{~Hz}, 3 \mathrm{H})$, $7.42(\mathrm{~s}, 1 \mathrm{H}), 7.27(\mathrm{~d}, J=8.6 \mathrm{~Hz}, 2 \mathrm{H}), 7.18(\mathrm{~d}, J=3.8 \mathrm{~Hz}, 1 \mathrm{H}), 3.23(\mathrm{dd}, J=13.3,6.5 \mathrm{~Hz}, 2 \mathrm{H}), 1.57-1.47(\mathrm{~m}$, 2H), $0.84(\mathrm{t}, J=7.3 \mathrm{~Hz}, 3 \mathrm{H}) .{ }^{13} \mathrm{C}-\mathrm{NMR}\left(100 \mathrm{MHz}, \mathrm{DMSO}-d_{6}, \mathrm{ppm}\right) \delta 165.73,163.15,156.61,152.52$, 150.33(2,C), 149.45, 142.38, 136.20, 135.87, 134.06, 129.69(2,C), 128.18(2,C), 122.39(2,C), 121.29(2,C), 114.13(2,C), 108.99, 40.58, 22.34, 11.25. TOF MS ES+ $(\mathrm{m} / \mathrm{z}):[\mathrm{M}+\mathrm{H}]^{+}$, calcd for $\mathrm{C}_{25} \mathrm{H}_{19} \mathrm{ClF}_{4} \mathrm{~N}_{6} \mathrm{O}_{3}$ : 563.1222, found, 563.1216.

4-(4-(1-(2-chloro-5-(trifluoromethyl)phenyl)-5-(trifluoromethyl)-1H-1,2,3-triazole-4-carboxamido)phenoxy)-Npropylpicolinamide (B8) White solid; Yield: $56.7 \%$; m.p.: $143.3-143.7^{\circ} \mathrm{C} ;{ }^{1} \mathrm{H}-\mathrm{NMR}\left(400 \mathrm{MHz}\right.$, DMSO- $d_{6}$, ppm) $\delta 11.30(\mathrm{~s}, 1 \mathrm{H}), 8.81(\mathrm{~s}, 1 \mathrm{H}), 8.65(\mathrm{~s}, 1 \mathrm{H}), 8.53(\mathrm{~d}, J=4.9 \mathrm{~Hz}, 1 \mathrm{H}), 8.21(\mathrm{~d}, J=8.0 \mathrm{~Hz}, 1 \mathrm{H}), 8.15$ $(\mathrm{d}, J=7.9 \mathrm{~Hz}, 1 \mathrm{H}), 8.00(\mathrm{~d}, J=8.4 \mathrm{~Hz}, 2 \mathrm{H}), 7.42(\mathrm{~s}, 1 \mathrm{H}), 7.27(\mathrm{~d}, J=8.5 \mathrm{~Hz}, 2 \mathrm{H}), 7.19(\mathrm{~d}, J=2.1 \mathrm{~Hz}$, $1 \mathrm{H}), 3.22(\mathrm{dd}, J=12.2,6.0 \mathrm{~Hz}, 2 \mathrm{H}), 1.52(\mathrm{dq}, J=13.9,7.1 \mathrm{~Hz}, 2 \mathrm{H}), 0.84(\mathrm{t}, J=7.1 \mathrm{~Hz}, 3 \mathrm{H}) .{ }^{13} \mathrm{C}-\mathrm{NMR}$ $\left(100 \mathrm{MHz}\right.$, DMSO- $d_{6}$, ppm) $\delta 165.72,163.14,156.13,152.54,150.37(2, \mathrm{C}), 149.56,141.97,135.71,135.05$, 133.58, 131.78(2,C), 131.49, 130.44, 127.03, 122.63(2,C), 121.28(2,C), 114.18(2,C), 108.96, 40.58, 22.33, 11.25. TOF MS ES+ $(\mathrm{m} / \mathrm{z}):[\mathrm{M}+\mathrm{H}]^{+}$, calcd for $\mathrm{C}_{26} \mathrm{H}_{19} \mathrm{ClF}_{6} \mathrm{~N}_{6} \mathrm{O}_{3}: 613.1190$, found, 613.1189.

4-(4-(1-(4-chloro-3-(trifluoromethyl)phenyl)-5-(trifluoromethyl)-1H-1,2,3-triazole-4-carboxamido)phenoxy)-Npropylpicolinamide (B9) Light yellow solid; Yield: 66.3\%; m.p.: $155.5-155.8{ }^{\circ} \mathrm{C} ;{ }^{1} \mathrm{H}-\mathrm{NMR}(400 \mathrm{MHz}$, DMSO- $\left.d_{6}, \mathrm{ppm}\right) \delta 11.21(\mathrm{~s}, 1 \mathrm{H}), 8.81(\mathrm{~s}, 1 \mathrm{H}), 8.53(\mathrm{~d}, J=5.3 \mathrm{~Hz}, 1 \mathrm{H}), 8.44(\mathrm{~s}, 1 \mathrm{H}), 8.17(\mathrm{~d}, J=8.1 \mathrm{~Hz}, 1 \mathrm{H})$, $8.10(\mathrm{~d}, J=8.4 \mathrm{~Hz}, 1 \mathrm{H}), 7.99(\mathrm{~d}, J=8.7 \mathrm{~Hz}, 2 \mathrm{H}), 7.41(\mathrm{~s}, 1 \mathrm{H}), 7.27(\mathrm{~d}, J=8.6 \mathrm{~Hz}, 2 \mathrm{H}), 7.19(\mathrm{~d}, J=2.9 \mathrm{~Hz}$, $1 \mathrm{H}), 3.22(\mathrm{dd}, J=12.8,6.2 \mathrm{~Hz}, 2 \mathrm{H}), 1.52(\mathrm{dq}, J=14.8,7.4 \mathrm{~Hz}, 2 \mathrm{H}), 0.84(\mathrm{t}, J=7.3 \mathrm{~Hz}, 3 \mathrm{H})$. TOF MS ES+ $(\mathrm{m} / \mathrm{z}):[\mathrm{M}+\mathrm{H}]^{+}$, calcd for $\mathrm{C}_{26} \mathrm{H}_{19} \mathrm{ClF}_{6} \mathrm{~N}_{6} \mathrm{O}_{3}$ : 613.1190, found, 613.1188 .

4-(2-fluoro-4-(5-methyl-1-phenyl-1H-1,2,3-triazole-4-carboxamido)phenoxy)-N-propylpicolinamide (B10) White solid; Yield: 76.8\%; m.p.: $143.3-143.7^{\circ} \mathrm{C} ;{ }^{1} \mathrm{H}-\mathrm{NMR}\left(400 \mathrm{MHz}, \mathrm{DMSO}-d_{6}, \mathrm{ppm}\right) \delta 10.96(\mathrm{~s}, 1 \mathrm{H}), 8.83$ (s, $1 \mathrm{H}), 8.54(\mathrm{~d}, J=5.4 \mathrm{~Hz}, 1 \mathrm{H}), 8.11(\mathrm{~d}, J=13.2 \mathrm{~Hz}, 1 \mathrm{H}), 7.86(\mathrm{~d}, J=8.7 \mathrm{~Hz}, 1 \mathrm{H}), 7.67(\mathrm{~d}, J=2.6 \mathrm{~Hz}, 5 \mathrm{H})$, $7.48-7.39(\mathrm{~m}, 2 \mathrm{H}), 7.23(\mathrm{~d}, J=4.7 \mathrm{~Hz}, 1 \mathrm{H}), 3.23(\mathrm{dd}, J=12.9,6.3 \mathrm{~Hz}, 2 \mathrm{H}), 2.59(\mathrm{~s}, 3 \mathrm{H}), 1.57-1.47(\mathrm{~m}, 2 \mathrm{H})$, $0.84(\mathrm{t}, J=7.3 \mathrm{~Hz}, 3 \mathrm{H}) .{ }^{13} \mathrm{C}-\mathrm{NMR}\left(100 \mathrm{MHz}, \mathrm{DMSO}-d_{6}, \mathrm{ppm}\right) \delta 165.66,163.43,160.15,153.09,150.87(2, \mathrm{C})$, 138.46, 138.29, 135.61, 130.48, 130.09(3,C), 125.84(3,C), 124.07, 117.64, 113.82, 109.37, 108.46, 41.02, 22.73, 11.67, 9.86. TOF MS ES+ $(\mathrm{m} / \mathrm{z}):[\mathrm{M}+\mathrm{H}]^{+}$, calcd for $\mathrm{C}_{25} \mathrm{H}_{23} \mathrm{FN}_{6} \mathrm{O}_{3}: 475.1894$, found, 475.1894.

4-(2-fluoro-4-(1-(4-fluorophenyl)-5-methyl-1H-1,2,3-triazole-4-carboxamido)phenoxy)-N-propylpicolinamide (B11) White solid; Yield: 65.1\%; m.p.: $143.5-143.8^{\circ} \mathrm{C} ;{ }^{1} \mathrm{H}-\mathrm{NMR}\left(400 \mathrm{MHz}, \mathrm{DMSO}-d_{6}, \mathrm{ppm}\right) \delta 10.95$ (s, $1 \mathrm{H}), 8.82(\mathrm{~s}, 1 \mathrm{H}), 8.54(\mathrm{~d}, J=5.1 \mathrm{~Hz}, 1 \mathrm{H}), 8.10(\mathrm{~d}, J=12.7 \mathrm{~Hz}, 1 \mathrm{H}), 7.86(\mathrm{~d}, J=8.6 \mathrm{~Hz}, 1 \mathrm{H}), 7.76(\mathrm{~s}, 2 \mathrm{H})$, $7.51(\mathrm{t}, J=8.4 \mathrm{~Hz}, 2 \mathrm{H}), 7.44(\mathrm{~d}, J=12.9 \mathrm{~Hz}, 2 \mathrm{H}), 7.22(\mathrm{~d}, J=2.5 \mathrm{~Hz}, 1 \mathrm{H}), 3.22(\mathrm{~d}, J=6.0 \mathrm{~Hz}, 2 \mathrm{H}), 2.58(\mathrm{~s}$, $3 \mathrm{H}), 1.51(\mathrm{dd}, J=13.9,6.9 \mathrm{~Hz}, 2 \mathrm{H}), 0.84(\mathrm{t}, J=7.2 \mathrm{~Hz}, 3 \mathrm{H}) .{ }^{13} \mathrm{C}-\mathrm{NMR}\left(100 \mathrm{MHz}\right.$, DMSO- $\left.d_{6}, \mathrm{ppm}\right) \delta$ 165.65, 164.20, 163.42, 161.74, 160.11, 153.08, 150.88, 138.75, 138.22, 131.99, 128.44, 128.35, 124.08, 117.65, 117.18(2,C), 116.95, 113.83, 109.60, 109.38, 108.44, 41.01, 22.73, 11.67, 9.78. TOF MS ES+ $(\mathrm{m} / \mathrm{z}):[\mathrm{M}+\mathrm{H}]^{+}$, calcd for $\mathrm{C}_{25} \mathrm{H}_{22} \mathrm{~F}_{2} \mathrm{~N}_{6} \mathrm{O}_{3}: 493.1800$, found, 493.1797 .

4-(2-fluoro-4-(5-methyl-1-(2-(trifluoromethoxy)phenyl)-1H-1,2,3-triazole-4-carboxamido)phenoxy)-N-propylpicolinamide (B12) Light yellow solid; Yield: 63.2\%; m.p.: $132.6-132.9{ }^{\circ} \mathrm{C} ;{ }^{1} \mathrm{H}-\mathrm{NMR}\left(400 \mathrm{MHz}\right.$, DMSO- $\left.d_{6}, \mathrm{ppm}\right) \delta$ $10.99(\mathrm{~s}, 1 \mathrm{H}), 8.82(\mathrm{~s}, 1 \mathrm{H}), 8.55(\mathrm{~d}, J=5.6 \mathrm{~Hz}, 1 \mathrm{H}), 8.10(\mathrm{~d}, J=13.2 \mathrm{~Hz}, 1 \mathrm{H}), 7.88(\mathrm{~d}, J=7.5 \mathrm{~Hz}, 1 \mathrm{H}), 7.85$ $(\mathrm{d}, J=8.0 \mathrm{~Hz}, 2 \mathrm{H}), 7.79(\mathrm{~d}, J=8.4 \mathrm{~Hz}, 1 \mathrm{H}), 7.73(\mathrm{t}, J=7.5 \mathrm{~Hz}, 1 \mathrm{H}), 7.46(\mathrm{~d}, J=9.0 \mathrm{~Hz}, 1 \mathrm{H}), 7.41(\mathrm{~d}$, $J=2.5 \mathrm{~Hz}, 1 \mathrm{H}), 7.23(\mathrm{dd}, J=5.5,2.6 \mathrm{~Hz}, 1 \mathrm{H}), 3.26-3.20(\mathrm{~m}, 2 \mathrm{H}), 2.46(\mathrm{~s}, 3 \mathrm{H}), 1.58-1.47(\mathrm{~m}, 2 \mathrm{H}), 0.85(\mathrm{t}$, $J=7.4 \mathrm{~Hz}, 3 \mathrm{H})$. TOF MS ES+ $(\mathrm{m} / \mathrm{z}):[\mathrm{M}+\mathrm{H}]^{+}$, calcd for $\mathrm{C}_{26} \mathrm{H}_{22} \mathrm{~F}_{4} \mathrm{~N}_{6} \mathrm{O}_{4}: 559.1717$, found, 559.1717.

4-(4-(1-(4-chlorophenyl)-5-(trifluoromethyl)-1H-1,2,3-triazole-4-carboxamido)-2-fluorophenoxy)-N-propylpicolinamide (B13) Light yellow solid; Yield: 76.3\%; m.p.: $176.5-176.8^{\circ} \mathrm{C} ;{ }^{1} \mathrm{H}-\mathrm{NMR}\left(400 \mathrm{MHz}\right.$, DMSO- $\left.d_{6}, \mathrm{ppm}\right) \delta$ $11.37(\mathrm{~s}, 1 \mathrm{H}), 8.81(\mathrm{~s}, 1 \mathrm{H}), 8.55(\mathrm{~d}, J=5.3 \mathrm{~Hz}, 1 \mathrm{H}), 8.06(\mathrm{~d}, J=12.8 \mathrm{~Hz}, 1 \mathrm{H}), 7.79(\mathrm{~d}, J=7.4 \mathrm{~Hz}, 5 \mathrm{H})$, $7.48(\mathrm{~d}, J=8.9 \mathrm{~Hz}, 1 \mathrm{H}), 7.44(\mathrm{~s}, 1 \mathrm{H}), 7.27-7.20(\mathrm{~m}, 1 \mathrm{H}), 3.23(\mathrm{~d}, J=6.1 \mathrm{~Hz}, 2 \mathrm{H}), 1.52(\mathrm{dd}, J=14.1$, $7.1 \mathrm{~Hz}, 2 \mathrm{H}), 0.84(\mathrm{t}, J=7.3 \mathrm{~Hz}, 3 \mathrm{H})$. TOF MS ES+ $(\mathrm{m} / \mathrm{z}):[\mathrm{M}+\mathrm{H}]^{+}$, calcd for $\mathrm{C}_{25} \mathrm{H}_{19} \mathrm{ClF}_{4} \mathrm{~N}_{6} \mathrm{O}_{3}: 563.1222$, found, 563.1216 . 
4-(2-fluoro-4-(5-(trifluoromethyl)-1-(2-(trifluoromethyl)phenyl)-1H-1,2,3-triazole-4-carboxamido)phenoxy)-Npropylpicolinamide (B14) Light yellow solid; Yield: 79.6\%; m.p.: $172.8-173.1{ }^{\circ} \mathrm{C} ;{ }^{1} \mathrm{H}-\mathrm{NMR}(400 \mathrm{MHz}$, DMSO- $\left.d_{6}, \mathrm{ppm}\right) \delta 11.43(\mathrm{~s}, 1 \mathrm{H}), 8.82(\mathrm{~s}, 1 \mathrm{H}), 8.55(\mathrm{~d}, J=5.3 \mathrm{~Hz}, 1 \mathrm{H}), 8.12(\mathrm{~s}, 1 \mathrm{H}), 8.09(\mathrm{~d}, J=4.7 \mathrm{~Hz}, 1 \mathrm{H})$, $8.05(\mathrm{~s}, 1 \mathrm{H}), 8.00(\mathrm{~d}, J=9.1 \mathrm{~Hz}, 2 \mathrm{H}), 7.84(\mathrm{~d}, J=8.3 \mathrm{~Hz}, 1 \mathrm{H}), 7.49(\mathrm{~d}, J=8.9 \mathrm{~Hz}, 1 \mathrm{H}), 7.44(\mathrm{~s}, 1 \mathrm{H}), 7.24(\mathrm{~d}$, $J=2.5 \mathrm{~Hz}, 1 \mathrm{H}), 3.23(\mathrm{~d}, J=5.6 \mathrm{~Hz}, 2 \mathrm{H}), 1.55-1.49(\mathrm{~m}, 2 \mathrm{H}), 0.84(\mathrm{t}, J=7.2 \mathrm{~Hz}, 3 \mathrm{H}) .{ }^{13} \mathrm{C}-\mathrm{NMR}(100 \mathrm{MHz}$, DMSO- $d_{6}$, ppm) $\delta 165.15,163.01,156.39,152.70,150.48(2, C), 141.52,134.25(2, C), 134.18,132.86,132.00$, 129.99(2,C), 127.65, 123.86(2,C), 117.59, 113.43(2,C), 109.61, 109.39, 108.12, 40.60, 22.31, 11.21. TOF MS $\mathrm{ES}+(\mathrm{m} / \mathrm{z}):[\mathrm{M}+\mathrm{H}]^{+}$, calcd for $\mathrm{C}_{26} \mathrm{H}_{22} \mathrm{~F}_{4} \mathrm{~N}_{6} \mathrm{O}_{3}: 543.1614$, found, 543.1616.

4-(4-(1-(3,4-difluorophenyl)-5-(trifluoromethyl)-1H-1,2,3-triazole-4-carboxamido)-2-fluorophenoxy)-N-propylpicolinamide (B15) White solid; Yield: $55.4 \%$; m.p.: $134.4-134.8^{\circ} \mathrm{C} ;{ }^{1} \mathrm{H}-\mathrm{NMR}\left(400 \mathrm{MHz}, \mathrm{DMSO}-d_{6}, \mathrm{ppm}\right) \delta 11.40$ $(\mathrm{s}, 1 \mathrm{H}), 8.83(\mathrm{~s}, 1 \mathrm{H}), 8.55(\mathrm{~d}, J=5.4 \mathrm{~Hz}, 1 \mathrm{H}), 8.13(\mathrm{~d}, J=9.0 \mathrm{~Hz}, 1 \mathrm{H}), 8.06(\mathrm{~d}, J=13.0 \mathrm{~Hz}, 1 \mathrm{H}), 7.82$ $(\mathrm{d}, J=7.0 \mathrm{~Hz}, 2 \mathrm{H}), 7.74(\mathrm{~s}, 1 \mathrm{H}), 7.48(\mathrm{t}, J=8.8 \mathrm{~Hz}, 1 \mathrm{H}), 7.42(\mathrm{~s}, 1 \mathrm{H}), 7.25(\mathrm{~d}, J=2.0 \mathrm{~Hz}, 1 \mathrm{H}), 3.22(\mathrm{~d}$, $J=6.2 \mathrm{~Hz}, 2 \mathrm{H}), 1.52(\mathrm{~d}, J=7.1 \mathrm{~Hz}, 2 \mathrm{H}), 0.84(\mathrm{t}, J=7.1 \mathrm{~Hz}, 3 \mathrm{H})$. TOF MS ES+ $(\mathrm{m} / \mathrm{z}):[\mathrm{M}+\mathrm{H}]^{+}$, calcd for $\mathrm{C}_{26} \mathrm{H}_{19} \mathrm{~F}_{7} \mathrm{~N}_{6} \mathrm{O}_{3}:$ 597.1485, found, 597.1486.

4-(4-(1-(3-chloro-4-fluorophenyl)-5-(trifluoromethyl)-1H-1,2,3-triazole-4-carboxamido)-2-fluorophenoxy)-Npropylpicolinamide (B16) White solid; Yield: 59.7\%; m.p.: $163.3-163.5{ }^{\circ} \mathrm{C} ;{ }^{1} \mathrm{H}-\mathrm{NMR}\left(400 \mathrm{MHz}\right.$, DMSO- $\mathrm{d}_{6}$, ppm) $\delta 11.39(\mathrm{~s}, 1 \mathrm{H}), 8.82(\mathrm{t}, J=5.8 \mathrm{~Hz}, 1 \mathrm{H}), 8.56(\mathrm{~d}, J=5.6 \mathrm{~Hz}, 1 \mathrm{H}), 8.23(\mathrm{~d}, J=4.8 \mathrm{~Hz}, 1 \mathrm{H}), 8.06$ $(\mathrm{d}, J=12.9 \mathrm{~Hz}, 1 \mathrm{H}), 7.88(\mathrm{~d}, J=8.5 \mathrm{~Hz}, 1 \mathrm{H}), 7.83(\mathrm{~d}, J=8.8 \mathrm{~Hz}, 1 \mathrm{H}), 7.77(\mathrm{t}, J=8.9 \mathrm{~Hz}, 1 \mathrm{H}), 7.48(\mathrm{t}$, $J=9.0 \mathrm{~Hz}, 1 \mathrm{H}), 7.42(\mathrm{~s}, 1 \mathrm{H}), 7.25(\mathrm{~d}, J=5.4 \mathrm{~Hz}, 1 \mathrm{H}), 3.23(\mathrm{dd}, J=13.3,6.5 \mathrm{~Hz}, 2 \mathrm{H}), 1.53(\mathrm{dt}, J=14.5$, $7.4 \mathrm{~Hz}, 2 \mathrm{H}), 0.85(\mathrm{t}, J=7.4 \mathrm{~Hz}, 3 \mathrm{H})$. TOF MS ES+ $(\mathrm{m} / \mathrm{z}):[\mathrm{M}+\mathrm{H}]^{+}$, calcd for $\mathrm{C}_{25} \mathrm{H}_{18} \mathrm{ClF}_{5} \mathrm{~N}_{6} \mathrm{O}_{3}: 581.1127$, found, 581.1128 .

4-(4-(1-(2-chloro-5-(trifluoromethyl)phenyl)-5-(trifluoromethyl)-1H-1,2,3-triazole-4-carboxamido)-2fluorophenoxy)-N-propylpicolinamide (B17) White solid; Yield: $64.5 \%$; m.p.: $154.1-154.4{ }^{\circ} \mathrm{C} ;{ }^{1} \mathrm{H}-\mathrm{NMR}$ $\left(400 \mathrm{MHz}, \mathrm{DMSO}-\mathrm{d}_{6}, \mathrm{ppm}\right) \delta 11.48(\mathrm{~s}, 1 \mathrm{H}), 8.83(\mathrm{~s}, 1 \mathrm{H}), 8.65(\mathrm{~s}, 1 \mathrm{H}), 8.55(\mathrm{~d}, J=5.0 \mathrm{~Hz}, 1 \mathrm{H}), 8.21(\mathrm{~d}$, $J=7.8 \mathrm{~Hz}, 1 \mathrm{H}), 8.15(\mathrm{~d}, J=8.2 \mathrm{~Hz}, 1 \mathrm{H}), 8.07(\mathrm{~d}, J=12.9 \mathrm{~Hz}, 1 \mathrm{H}), 7.84(\mathrm{~d}, J=8.6 \mathrm{~Hz}, 1 \mathrm{H}), 7.49(\mathrm{t}$, $J=8.8 \mathrm{~Hz}, 1 \mathrm{H}), 7.43(\mathrm{~s}, 1 \mathrm{H}), 7.25(\mathrm{~d}, J=1.4 \mathrm{~Hz}, 1 \mathrm{H}), 3.23(\mathrm{~d}, J=6.0 \mathrm{~Hz}, 2 \mathrm{H}), 1.52(\mathrm{dd}, J=13.9,6.9 \mathrm{~Hz}$, $2 \mathrm{H}), 0.84(\mathrm{t}, J=7.3 \mathrm{~Hz}, 3 \mathrm{H})$. TOF MS ES+ $(\mathrm{m} / \mathrm{z}):[\mathrm{M}+\mathrm{H}]^{+}$, calcd for $\mathrm{C}_{26} \mathrm{H}_{18} \mathrm{ClF}_{7} \mathrm{~N}_{6} \mathrm{O}_{3}: 631.1089$, found, 631.1089 .

4-(4-(1-(4-chloro-3-(trifluoromethyl)phenyl)-5-(trifluoromethyl)-1H-1,2,3-triazole-4-carboxamido)-2fluorophenoxy)-N-propylpicolinamide (B18) White solid; Yield: 55.9\%; m.p.: $153.4-153.7{ }^{\circ} \mathrm{C} ;{ }^{1} \mathrm{H}-\mathrm{NMR}$ $\left(400 \mathrm{MHz}, \mathrm{DMSO}_{6} \mathrm{~d}_{6}, \mathrm{ppm}\right) \delta 11.41(\mathrm{~s}, 1 \mathrm{H}), 8.83(\mathrm{~s}, 1 \mathrm{H}), 8.56(\mathrm{~d}, J=5.3 \mathrm{~Hz}, 1 \mathrm{H}), 8.45(\mathrm{~s}, 1 \mathrm{H}), 8.18(\mathrm{~d}$, $J=8.4 \mathrm{~Hz}, 1 \mathrm{H}), 8.12-8.01(\mathrm{~m}, 2 \mathrm{H}), 7.84(\mathrm{~d}, J=8.4 \mathrm{~Hz}, 1 \mathrm{H}), 7.48(\mathrm{t}, J=8.9 \mathrm{~Hz}, 1 \mathrm{H}), 7.42(\mathrm{~s}, 1 \mathrm{H}), 7.25$ $(\mathrm{s}, 1 \mathrm{H}), 3.26-3.19(\mathrm{~m}, 2 \mathrm{H}), 1.52(\mathrm{dq}, J=14.4,7.0 \mathrm{~Hz}, 2 \mathrm{H}), 0.84(\mathrm{t}, J=7.2 \mathrm{~Hz}, 3 \mathrm{H})$. TOF MS ES+ $(\mathrm{m} / \mathrm{z})$ : $[\mathrm{M}+\mathrm{H}]^{+}$, calcd for $\mathrm{C}_{26} \mathrm{H}_{18} \mathrm{ClF}_{7} \mathrm{~N}_{6} \mathrm{O}_{3}: 631.1089$, found, 631.1096.

N-(3-fluoro-4-((2-(pyrrolidine-1-carbonyl)pyridin-4-yl)oxy) phenyl)-5-methyl-1-phenyl-1H-1,2,3-triazole-4carboxamide (B19) Light yellow solid; Yield: $63.2 \%$; m.p.: $169.7-170.0{ }^{\circ} \mathrm{C} ;{ }^{1} \mathrm{H}-\mathrm{NMR}$ (400 MHz, DMSO- $d_{6}$, ppm) $\delta 10.94(\mathrm{~s}, 1 \mathrm{H}), 8.50(\mathrm{~d}, J=4.4 \mathrm{~Hz}, 1 \mathrm{H}), 8.09(\mathrm{~d}, J=12.9 \mathrm{~Hz}, 1 \mathrm{H}), 7.84(\mathrm{~d}, J=8.4 \mathrm{~Hz}, 1 \mathrm{H}), 7.65(\mathrm{~d}$, $J=14.4 \mathrm{~Hz}, 5 \mathrm{H}), 7.42(\mathrm{t}, J=8.6 \mathrm{~Hz}, 1 \mathrm{H}), 7.13(\mathrm{~d}, J=14.2 \mathrm{~Hz}, 2 \mathrm{H}), 3.59(\mathrm{~s}, 2 \mathrm{H}), 3.45(\mathrm{~s}, 2 \mathrm{H}), 2.59(\mathrm{~s}, 3 \mathrm{H})$, $1.82(\mathrm{~s}, 4 \mathrm{H})$. TOF MS ES+ $(\mathrm{m} / \mathrm{z}):[\mathrm{M}+\mathrm{H}]^{+}$, calcd for $\mathrm{C}_{26} \mathrm{H}_{23} \mathrm{FN}_{6} \mathrm{O}_{3}: 487.1897$, found, 487.1902.

N-(3-fluoro-4-((2-(pyrrolidine-1-carbonyl)pyridin-4-yl)oxy)phenyl)-1-(4-fluorophenyl)-5-methyl-1H-1,2,3triazole-4-carboxamide (B20) Light yellow solid; Yield: 66.4\%; m.p.: $164.3-164.7^{\circ} \mathrm{C}$; ${ }^{1} \mathrm{H}-\mathrm{NMR}(400 \mathrm{MHz}$, DMSO- $\left.d_{6}, \mathrm{ppm}\right) \delta 10.94(\mathrm{~s}, 1 \mathrm{H}), 8.51(\mathrm{~d}, J=5.3 \mathrm{~Hz}, 1 \mathrm{H}), 8.09(\mathrm{~d}, J=13.2 \mathrm{~Hz}, 1 \mathrm{H}), 7.84(\mathrm{~d}, J=8.4 \mathrm{~Hz}$, $1 \mathrm{H}), 7.75(\mathrm{~d}, J=3.2 \mathrm{~Hz}, 2 \mathrm{H}), 7.51(\mathrm{t}, J=8.4 \mathrm{~Hz}, 2 \mathrm{H}), 7.42(\mathrm{t}, J=8.9 \mathrm{~Hz}, 1 \mathrm{H}), 7.18(\mathrm{~s}, 1 \mathrm{H}), 7.12(\mathrm{~d}$, $J=4.6 \mathrm{~Hz}, 1 \mathrm{H}), 3.59(\mathrm{~s}, 2 \mathrm{H}), 3.45(\mathrm{~s}, 2 \mathrm{H}), 2.57(\mathrm{~s}, 3 \mathrm{H}), 1.81(\mathrm{~s}, 4 \mathrm{H})$. TOF MS ES+ $(\mathrm{m} / \mathrm{z}):[\mathrm{M}+\mathrm{H}]^{+}$, calcd for $\mathrm{C}_{26} \mathrm{H}_{22} \mathrm{~F}_{2} \mathrm{~N}_{6} \mathrm{O}_{3}$ : 505.1800, found, 505.1807.

N-(3-fluoro-4-((2-(pyrrolidine-1-carbonyl)pyridin-4-yl)oxy) phenyl)-5-methyl-1-(2-(trifluoromethoxy)phenyl)1H-1,2,3-triazole-4-carboxamide (B21) White solid; Yield: 66.5\%; m.p.: $176.3-176.6{ }^{\circ} \mathrm{C} ;{ }^{1} \mathrm{H}-\mathrm{NMR}(400 \mathrm{MHz}$, 
DMSO-d $\left._{6}, \mathrm{ppm}\right) \delta 11.00(\mathrm{~s}, 1 \mathrm{H}), 8.51(\mathrm{~d}, J=4.9 \mathrm{~Hz}, 1 \mathrm{H}), 8.09(\mathrm{~d}, J=12.8 \mathrm{~Hz}, 1 \mathrm{H}), 7.89(\mathrm{~d}, J=7.3 \mathrm{~Hz}$, $1 \mathrm{H}), 7.85(\mathrm{~d}, J=8.0 \mathrm{~Hz}, 2 \mathrm{H}), 7.79(\mathrm{~d}, J=8.2 \mathrm{~Hz}, 1 \mathrm{H}), 7.75-7.70(\mathrm{~m}, 1 \mathrm{H}), 7.43(\mathrm{t}, J=8.6 \mathrm{~Hz}, 1 \mathrm{H}), 7.16$ $(\mathrm{s}, 1 \mathrm{H}), 7.11(\mathrm{~d}, J=1.9 \mathrm{~Hz}, 1 \mathrm{H}), 3.60(\mathrm{~s}, 2 \mathrm{H}), 3.46(\mathrm{~s}, 2 \mathrm{H}), 2.46(\mathrm{~s}, 3 \mathrm{H}), 1.82(\mathrm{~s}, 4 \mathrm{H})$. TOF MS ES+ (m/z): $[\mathrm{M}+\mathrm{H}]^{+}$, calcd for $\mathrm{C}_{27} \mathrm{H}_{22} \mathrm{~F}_{4} \mathrm{~N}_{6} \mathrm{O}_{4}: 571.1717$, found, 571.1722.

4-(2-fluoro-4-(5-methyl-1-phenyl-1H-1,2,3-triazole-4-carboxamido)phenoxy)-N-(2-(thiophen-2-yl)ethyl)picolinamide (B22) Light yellow solid; Yield: 61.9\%; m.p.: $124.6-125.0{ }^{\circ} \mathrm{C} ;{ }^{1} \mathrm{H}$ NMR $\left(400 \mathrm{MHz}\right.$, DMSO- $\left.d_{6}, \mathrm{ppm}\right) \delta$ $10.97(\mathrm{~s}, 1 \mathrm{H}), 8.98(\mathrm{t}, J=5.9 \mathrm{~Hz}, 1 \mathrm{H}), 8.55(\mathrm{~d}, J=5.6 \mathrm{~Hz}, 1 \mathrm{H}), 8.11(\mathrm{~d}, J=13.2 \mathrm{~Hz}, 1 \mathrm{H}), 7.86(\mathrm{~d}, J=8.8 \mathrm{~Hz}$, $1 \mathrm{H}), 7.67(\mathrm{~d}, J=2.3 \mathrm{~Hz}, 5 \mathrm{H}), 7.48-7.41(\mathrm{~m}, 2 \mathrm{H}), 7.32(\mathrm{~d}, J=4.9 \mathrm{~Hz}, 1 \mathrm{H}), 7.24(\mathrm{~d}, J=3.0 \mathrm{~Hz}, 1 \mathrm{H}), 6.96-6.91$ $(\mathrm{m}, 1 \mathrm{H}), 6.89(\mathrm{~d}, J=2.6 \mathrm{~Hz}, 1 \mathrm{H}), 3.54(\mathrm{dd}, J=13.4,6.8 \mathrm{~Hz}, 2 \mathrm{H}), 3.06(\mathrm{t}, J=7.1 \mathrm{~Hz}, 2 \mathrm{H}), 2.59(\mathrm{~s}, 3 \mathrm{H})$. TOF MS ES+ $(\mathrm{m} / \mathrm{z}):[\mathrm{M}+\mathrm{H}]^{+}$, calcd for $\mathrm{C}_{28} \mathrm{H}_{23} \mathrm{FN}_{6} \mathrm{O}_{3} \mathrm{~S}: 543.1614$, found, 543.1616.

4-(2-fluoro-4-(1-(4-fluorophenyl)-5-methyl-1H-1,2,3-triazole-4-carboxamido)phenoxy)-N-(2-(thiophen-2-yl) ethyl)picolinamide (B23) White solid; Yield: $51.7 \%$; m.p.: $110.4-110.8{ }^{\circ} \mathrm{C} ;{ }^{1} \mathrm{H}-\mathrm{NMR}\left(400 \mathrm{MHz}\right.$, DMSO- $d_{6}$, ppm) $\delta 10.99(\mathrm{~s}, 1 \mathrm{H}), 9.00(\mathrm{t}, J=5.7 \mathrm{~Hz}, 1 \mathrm{H}), 8.57(\mathrm{~d}, J=5.6 \mathrm{~Hz}, 1 \mathrm{H}), 8.13(\mathrm{~d}, J=13.2 \mathrm{~Hz}, 1 \mathrm{H}), 7.88$ $(\mathrm{d}, J=8.8 \mathrm{~Hz}, 1 \mathrm{H}), 7.79(\mathrm{~d}, J=4.8 \mathrm{~Hz}, 1 \mathrm{H}), 7.77(\mathrm{~d}, J=4.8 \mathrm{~Hz}, 1 \mathrm{H}), 7.54(\mathrm{t}, J=8.7 \mathrm{~Hz}, 2 \mathrm{H}), 7.47(\mathrm{~d}$, $J=9.1 \mathrm{~Hz}, 1 \mathrm{H}), 7.43(\mathrm{~d}, J=2.1 \mathrm{~Hz}, 1 \mathrm{H}), 7.34(\mathrm{~d}, J=4.6 \mathrm{~Hz}, 1 \mathrm{H}), 7.26(\mathrm{~d}, J=2.4 \mathrm{~Hz}, 1 \mathrm{H}), 6.98-6.94(\mathrm{~m}$, $1 \mathrm{H}), 6.91(\mathrm{~s}, 1 \mathrm{H}), 3.55(\mathrm{dd}, J=13.3,6.8 \mathrm{~Hz}, 2 \mathrm{H}), 3.08(\mathrm{t}, J=7.1 \mathrm{~Hz}, 2 \mathrm{H}), 2.60(\mathrm{~s}, 3 \mathrm{H})$. TOF MS ES+ $(\mathrm{m} / \mathrm{z})$ : $[\mathrm{M}+\mathrm{H}]^{+}$, calcd for $\mathrm{C}_{28} \mathrm{H}_{22} \mathrm{~F}_{2} \mathrm{~N}_{6} \mathrm{O}_{3} \mathrm{~S}: 561.1520$, found, 561.1529.

4-(2-fluoro-4-(5-methyl-1-(2-(trifluoromethoxy)phenyl)-1H-1,2,3-triazole-4-carboxamido)phenoxy)-N-(2-(thiophen2-yl)ethyl)picolinamide (B24) White solid; Yield: 56.6\%; m.p.: $103.4-103.7{ }^{\circ} \mathrm{C} ;{ }^{1} \mathrm{H}-\mathrm{NMR}(400 \mathrm{MHz}$, DMSO-d $_{6}$, ppm) $\delta 10.98(\mathrm{~s}, 1 \mathrm{H}), 8.94(\mathrm{~s}, 1 \mathrm{H}), 8.55(\mathrm{~d}, J=5.3 \mathrm{~Hz}, 1 \mathrm{H}), 8.10(\mathrm{~d}, J=13.2 \mathrm{~Hz}, 1 \mathrm{H}), 7.88(\mathrm{~d}$, $J=6.4 \mathrm{~Hz}, 2 \mathrm{H}), 7.84(\mathrm{~d}, J=7.0 \mathrm{~Hz}, 1 \mathrm{H}), 7.78(\mathrm{~d}, J=8.1 \mathrm{~Hz}, 1 \mathrm{H}), 7.72(\mathrm{t}, J=7.4 \mathrm{~Hz}, 1 \mathrm{H}), 7.44(\mathrm{t}, J=8.8 \mathrm{~Hz}$, $2 \mathrm{H}), 7.31(\mathrm{~d}, J=4.1 \mathrm{~Hz}, 1 \mathrm{H}), 7.23(\mathrm{~d}, J=2.3 \mathrm{~Hz}, 1 \mathrm{H}), 6.96-6.92(\mathrm{~m}, 1 \mathrm{H}), 6.90(\mathrm{~s}, 1 \mathrm{H}), 3.55(\mathrm{~d}, J=6.2 \mathrm{~Hz}$, $2 \mathrm{H}), 3.07(\mathrm{t}, J=6.9 \mathrm{~Hz}, 2 \mathrm{H}), 2.47(\mathrm{~s}, 3 \mathrm{H})$. TOF MS ES+ $(\mathrm{m} / \mathrm{z}):[\mathrm{M}+\mathrm{H}]^{+}$, calcd for $\mathrm{C}_{29} \mathrm{H}_{22} \mathrm{~F}_{4} \mathrm{~N}_{6} \mathrm{O}_{4} \mathrm{~S}$ : 627.1437 , found, 627.1439 .

4-(2-fluoro-4-(5-methyl-1-phenyl-1H-1,2,3-triazole-4-carboxamido)phenoxy)-N-(3-morpholinopropyl)picolinamide (B25) White solid; Yield: $42.6 \%$; m.p.: $108.3-108.6{ }^{\circ} \mathrm{C} ;{ }^{1} \mathrm{H}-\mathrm{NMR}\left(400 \mathrm{MHz}, \mathrm{DMSO}-d_{6}, \mathrm{ppm}\right) \delta 10.67$ (s, 1H), $9.05(\mathrm{~s}, 1 \mathrm{H}), 8.53(\mathrm{~s}, 1 \mathrm{H}), 8.03(\mathrm{~d}, J=7.5 \mathrm{~Hz}, 2 \mathrm{H}), 7.67(\mathrm{~s}, 5 \mathrm{H}), 7.45(\mathrm{~s}, 1 \mathrm{H}), 7.23(\mathrm{~d}, J=7.6 \mathrm{~Hz}$, $1 \mathrm{H}), 7.17(\mathrm{~s}, 1 \mathrm{H}), 3.64(\mathrm{~s}, 4 \mathrm{H}), 3.36(\mathrm{~s}, 2 \mathrm{H}), 2.60(\mathrm{~s}, 3 \mathrm{H}), 2.44(\mathrm{~s}, 6 \mathrm{H}), 1.72(\mathrm{~s}, 2 \mathrm{H}) .{ }^{13} \mathrm{C}-\mathrm{NMR}(100 \mathrm{MHz}$, DMSO- $d_{6}$, ppm) $\delta 166.25,163.53,159.92,152.85,150.72,149.29,138.56,138.11,136.82,135.67,130.44$, 130.10(2,C), 125.83(2,C), 122.70(2,C), 121.51(2,C), 114.53, 109.30, 66.25(2,C), 56.81, 53.53(2,C), 38.36, 25.59, 9.85. TOF MS ES+ $(\mathrm{m} / \mathrm{z}):[\mathrm{M}+\mathrm{H}]^{+}$, calcd for $\mathrm{C}_{29} \mathrm{H}_{30} \mathrm{FN}_{7} \mathrm{O}_{4}: 560.2421$, found, 560.2416.

4-(2-fluoro-4-(1-(4-fluorophenyl)-5-methyl-1H-1,2,3-triazole-4-carboxamido)phenoxy)-N-(3-morpholinopropyl) picolinamide (B26) White solid; Yield: 39.3\%; m.p.: 108.5-108.9 ${ }^{\circ} \mathrm{C} ;{ }^{1} \mathrm{H}-\mathrm{NMR}$ (400 MHz, DMSO- $d_{6}$, ppm) $\delta 10.73(\mathrm{~s}, 1 \mathrm{H}), 9.10(\mathrm{~s}, 1 \mathrm{H}), 8.52(\mathrm{~d}, J=3.7 \mathrm{~Hz}, 1 \mathrm{H}), 8.03(\mathrm{~d}, J=7.9 \mathrm{~Hz}, 2 \mathrm{H}), 7.76(\mathrm{~s}, 2 \mathrm{H}), 7.52$ $(\mathrm{d}, J=6.9 \mathrm{~Hz}, 2 \mathrm{H}), 7.43(\mathrm{~s}, 1 \mathrm{H}), 7.23(\mathrm{~d}, J=7.9 \mathrm{~Hz}, 2 \mathrm{H}), 3.61(\mathrm{~s}, 4 \mathrm{H}), 3.35(\mathrm{~s}, 2 \mathrm{H}), 2.59(\mathrm{~s}, 3 \mathrm{H}), 2.34(\mathrm{~s}$, 6H), 1.68 (s, 2H). ${ }^{13} \mathrm{C}-\mathrm{NMR}(100 \mathrm{MHz}$, DMSO-d 6 , ppm) $\delta 166.25,163.48,159.87,152.90,150.69,149.33$, 138.38, 136.78, 132.06, 128.39, 128.30, 122.71(2,C), 121.46(2,C), 117.16(2,C), 116.93(2,C), 114.50, 109.32, 66.54(2,C), 57.08, 53.77(2,C), 38.55, 25.80, 9.74. TOF MS ES+ $(\mathrm{m} / \mathrm{z})$ : $[\mathrm{M}+\mathrm{H}]^{+}$, calcd for $\mathrm{C}_{29} \mathrm{H}_{29} \mathrm{~F}_{2} \mathrm{~N}_{7} \mathrm{O}_{4}$ : 578.2327, found, 578.2347 .

4-(2-fluoro-4-(5-methyl-1-(2-(trifluoromethoxy)phenyl)-1H-1,2,3-triazole-4-carboxamido)phenoxy)-N-(3morpholinopropyl)picolinamide (B27) White solid; Yield: $41.0 \%$; m.p.: $97.6-97.9^{\circ} \mathrm{C} ;{ }^{1} \mathrm{H}-\mathrm{NMR}(400 \mathrm{MHz}$, DMSO-d $\left._{6}, \mathrm{ppm}\right) \delta 10.78(\mathrm{~s}, 1 \mathrm{H}), 9.05(\mathrm{~s}, 1 \mathrm{H}), 8.54(\mathrm{~s}, 1 \mathrm{H}), 7.99(\mathrm{~d}, J=5.2 \mathrm{~Hz}, 2 \mathrm{H}), 7.86(\mathrm{~d}, J=3.8 \mathrm{~Hz}$, 2H), $7.79(\mathrm{~s}, 1 \mathrm{H}), 7.73(\mathrm{~s}, 1 \mathrm{H}), 7.41(\mathrm{~s}, 1 \mathrm{H}), 7.23(\mathrm{~d}, J=6.1 \mathrm{~Hz}, 2 \mathrm{H}), 3.91(\mathrm{~d}, J=8.3 \mathrm{~Hz}, 2 \mathrm{H}), 3.85(\mathrm{~d}$, $J=11.1 \mathrm{~Hz}, 2 \mathrm{H}), 3.36(\mathrm{~d}, J=5.0 \mathrm{~Hz}, 2 \mathrm{H}), 3.06(\mathrm{~s}, 4 \mathrm{H}), 2.45(\mathrm{~s}, 2 \mathrm{H}), 1.98(\mathrm{~s}, 2 \mathrm{H})$. TOF MS ES+ $(\mathrm{m} / \mathrm{z})$ : $[\mathrm{M}+\mathrm{H}]^{+}$, calcd for $\mathrm{C}_{30} \mathrm{H}_{29} \mathrm{~F}_{4} \mathrm{~N}_{7} \mathrm{O}_{5}: 643.1059$, found, 643.1094 .

${ }^{1} \mathrm{H}-\mathrm{NMR}$ spectra of representative target compounds (B1, B6, B12, B13, B20, B25, and B26), ${ }^{13} \mathrm{C}-\mathrm{NMR}$ spectra of representative target compounds (B6, B7, B10, B11, B14, B25, and B26), 
and TOF-MS spectra of representative target compounds (B13, B17, B19, B21, B22, B25, and B26) can be seen in the Supplementary Materials.

\subsection{Antitumority Assay}

The antitumor activities of target compounds were determined by the MTT method using Golvatinib as a positive control. All cancer cell lines (A549, HeLa, and MCF-7) were cultured with Dulbecco Modified Eagle Medium (DMEM) or Roswell Park Memorial Institute (1640) containing $10 \%$ fetal bovine serum and $0.1 \%$ penicillin-streptomycin, under ambient conditions of $5 \% \mathrm{CO}_{2}$ and $37^{\circ} \mathrm{C}$. Cells were digested with an appropriate amount of Trypsin-EDTA solution to obtain the cell suspension, which was diluted with medium and inoculated into 96 -well plates at $5^{*} 10^{4}$ cells per well. After cells were incubated for $24 \mathrm{~h}$, the target compounds diluted by medium to suitable concentrations were added into 96-well plates, and the cells were cultured continue for $72 \mathrm{~h}$. Next, the medium was removed, and then thiazolyl blue tetrazolium bromide (MTT) was added to each well to treat cells for $3.5 \mathrm{~h}$. Ultimately, dimethyl sulfoxide (DMSO) was added to each well after removal of MTT and the absorbance values were measured with the ELISA (enzyme-linked immunosorbent assay) reader. All antitumor activities were tested for three times. The $\mathrm{IC}_{50}$ values were the average of three measurements and were calculated using the Bacus Laboratories Incorporated Slide Scanner (Bliss) software.

\subsection{Dose-Dependent Test}

The dose-dependent effect of compound B26 on A549 cells was tested by the MTT method using Golvatinib as a positive control. The experimental procedure was identical to that of the cytotoxic activity, wherein the concentration of the test compound was configured to be seven and the cytotoxic activity was five. Seven different concentrations of compound B26 treated on A549 cells to obtain the corresponding inhibition rates. Experimental data was obtained by Orange (2018 64 bit) software based on the inhibition rate.

\subsection{Cell Morphology Studies}

Cell morphology studies aimed to explore the morphological changes of A549 cells with and without treatment with compound B26, and the cell morphology was visualized by acridine orange (AO) staining. The culture environment of A549 cells was consistent with that in the antitumor activity experiments. Cells were digested with Trypsin-EDTA solution to get the cell suspension, which was diluted with 1640 medium and inoculated into a 24 -well plate at $2 * 10^{4}$ cells per well. After incubating for $12 \mathrm{~h}$, compound B26 diluted to suitable concentrations by 1640 medium was added into a 24-well plate, and cell culture was continued for $12 \mathrm{~h}$. Then, the 1640 medium in the well plate was removed and every well were washed three times with phosphate buffer saline (PBS). After washing with PBS three times, A549 cells were treated with AO for 15 min. A549 cells were washed three times with PBS again, and the cell morphology distribution was observed directly by a fluorescence microscope. Ultimately, the picture is exported via computer.

\subsection{Cell Cycle Study}

A549 cells were seeded into six-well plates at $1^{*} 10^{5}$ cells per well and incubated for $24 \mathrm{~h}$. Then, the medium containing DMEM (control, without compound) or compound B26 with different concentrations was added to the culture plate, and A549 cells were further cultured for $24 \mathrm{~h}$. Then, A549 cells were collected into a centrifuge tube and fixed with a small amount of ice-cold $70 \%$ ethanol at $4{ }^{\circ} \mathrm{C}$ for $6-12 \mathrm{~h}$. Cells washed three times with PBS were incubated with Rnase $(1 \mathrm{mg} / \mathrm{mL}$, diluted with PBS) for $30 \mathrm{~min}$ at room temperature. Finally, propidium iodide (PI) was added to staining without light for $30 \mathrm{~min}$ at room temperature, and the DNA content was measured by flow cytometry within $1 \mathrm{~h}$. Experimental data was obtained by Modify software. 


\section{6. c-Met Kinase Assay}

The kinase assay was implemented through Mobility shift assay. The Mixture the configured available Brij-35 (0.0015\%) and $50 \mathrm{mM}$ HEPES ( $\mathrm{pH}=7.5)$ to get a kinase buffer base. Then, compounds B25, B26, and B27 were configured to five concentrations using dimethyl sulfoxide. The kinase buffer containing the compounds or dimethyl sulfoxide was added to 96-well plates and mixed on the shaker for fifteen minutes. Next, the solution was transferred in duplicate from a 96-well plate to a 384-well plate, and then an enzyme solution (c-Met kinase mixed with kinase buffer) was added to each well. After incubation of the 384-well plate for $10 \mathrm{~min}$ at room temperature, a $2.5^{*}$ peptide solution (formed by the addition of FAM-labeled peptide and ATP to the kinase base buffer) was added to each well. After incubation at $28^{\circ} \mathrm{C}$ for a certain period of time, a stop buffer was added to each well for stop the reaction. The inhibition value is obtained by converting the conversion data on the caliper. The formula is that percent inhibition $=(\max -$ conversion $) /(\max -\min ) * 100$. Among them, "max" stands for DMSO control, "min" stands for low control. Finally, the $\mathrm{IC}_{50}$ values were obtained by fitting the inhibition rate data using the XLFit excel add-in version software.

\subsection{Molecular Docking Study}

All the molecular docking simulations were performed by the AutoDock 4.2 software. The crystal structure of c-Met (PDB code: 3LQ8) used in the docking was downloaded from http://www.rcsb.org/. The preparation process of the protein for docking mainly involves the addition of hydrogen atoms and charges, elimination of unrelated water molecules, immobilization of exact residues, and removal of endogenous ligands (Foretinib), etc. The preparation process of the molecules for docking mainly includes the addition of hydrogen atoms and charges. Then the prepared molecules (target compounds) were docked to the certified binding site of c-Met protein. Subsequently, the genetic algorithm was used for energy optimization. All the docking results were modified and processed by PyMOL 1.8.x software (https://pymol.org).

\section{Conclusions}

In conclusion, a series of 4-(pyridin-4-yloxy)benzamide derivatives bearing a triazole fragment were designed and synthesized. In addition, we evaluated them for antitumor activity against three cancer cell lines and c-Met kinase activity (only for compounds B25-B27) in vitro. The pharmacological results indicated that most compounds showed moderate antitumor activity against the three cancer cell lines. In particular, compound B26 showed excellent inhibitory activity with $\mathrm{IC}_{50}$ values of 3.22, 4.33, and $5.82 \mu \mathrm{M}$ against A549, HeLa, and MCF-7 cell lines, which were more potent than Golvatinib, respectively. The SARs study indicated that the introduction of a morpholino group in the hydrophilic region was more favorable than an alkane chain in terms of antitumor activity, and a single electron-withdrawing substituent (such as a fluorine atom) on the terminal phenyl ring improved the inhibitory activity of the target compounds. Further studies will be carried out in the near future.

Supplementary Materials: The Supplementary Materials are available online at http://www.mdpi.com/1420-3049/ 25/1/10/s1.

Author Contributions: P.Z., Q.T. and J.C. conceived and designed the experiments; H.X., J.Z., Q.Z., Z.X. and H.Z. performed the experiments and statistics analysis; J.C. and H.X. completed the molecular docking simulation and H.X. started the project and wrote the paper. All authors have read and agreed to the published version of the manuscript.

Funding: We gratefully acknowledge the generous support provided by Natural Science Foundation of National Natural Science Foundation of China (NSFC No. 81660572), Jiangxi Province (20171BAB215071, 20192ACBL21009) and Top-notch talent project of Jiangxi Science \& Technology Normal University (2016QNBJRC002).

Conflicts of Interest: The authors declare no conflict of interest. 


\section{References}

1. Miller, K.D.; Nogueira, L.; Mariotto, B.; Rowland, J.H.; Yabroff, K.R.; Alfano, C.M.; DVM, J.A.; Kramer, J.L.; Siegel, R.L. Cancer Treatment and Survivorship Statistics. CA Cancer J. Clin. 2016, 66, 271-289. [CrossRef] [PubMed]

2. Luo, T.; Zhang, S.G.; Zhu, L.F.; Zhang, F.X.; Li, W.; Zhao, K.; Wen, X.X.; Yu, M.; Zhan, Y.Q.; Chen, H.; et al. A Selective c-Met and Trks Inhibitor Indo5 Suppresses Hepatocellular Carcinoma Growth. J. Exp. Clin. Canc. Res. 2019, 38, 130-143. [CrossRef] [PubMed]

3. Moslehi, J.J.; Michael, D. Tyrosine Kinase Inhibitor-Associated Cardiovascular Toxicity in Chronic Myeloid Leukemia. J. Clin. Oncol. 2015, 33, 4210-4222. [CrossRef] [PubMed]

4. Bouattour, M.; Raymond, E.; Qin, S.; Cheng, A.L.; Stammberger, U.; Locatelli, G.; Faivre, S. Recent Developments of c-Met as a Therapeutic Target in Hepatocellular Carcinoma. Hepatology 2018, 67, 1132-1149. [CrossRef] [PubMed]

5. Kim, H.J.; Kang, S.K.; Kwon, W.S.; Kim, S.T.; Jeong, I.; Jeung, H.C.; Kragh, M.; Horak, I.D.; Chung, H.C.; Rha, S.Y. Forty-Nine Gastric Cancer Cell Lines with Integrative Genomic Profiling for Development of c-Met Inhibitor. Nt. J. Cancer 2018, 143, 151-159. [CrossRef] [PubMed]

6. Hong, D.S.; LoRusso, P.; Hamid, O.; Janku, F.; Kittaneh, M.; Catenacci, D.V.T.; Chan, E.; Bekaii-Saab, T.; Gadgeel, S.M.; Loberg, R.T.; et al. Phase I Study of AMG 337, a Highly Selective Small-Molecule Met Inhibitor, in Patients with Advanced Solid Tumors. Clin. Cancer Res. 2019, 25, 2403-2413. [CrossRef] [PubMed]

7. Liu, Y.; Jin, S.Y.; Peng, X.; Lu, D.; Zeng, L.M.; Sun, Y.M.; Ai, J.; Geng, M.Y.; Hu, Y.H. Pyridazinone Derivatives Displaying Highly Potent and Selective Inhibitory Activities Against c-Met Tyrosine Kinase. Eur. J. Med. Chem. 2016, 108, 322-333. [CrossRef] [PubMed]

8. Li, M.J.; Wu, G.Z.; Kaas, Q.; Jiang, T.; Yu, R.L. Development of Efficient Docking Strategies and Structure-Activity Relationship Study of the c-Met Type II Inhibitors. J. Mol. Graph Model 2017, 75, 241-249. [CrossRef] [PubMed]

9. Zhao, Y.M.; Zhang, J.K.; Zhuang, R.X.; He, R.Y.; Xi, J.J.; Pan, X.W.; Shao, Y.D.; Pan, Y.M.; Sun, J.J.; Cai, Z.B.; et al. Synthesis and Evaluation of a Series of Pyridine and Pyrimidine Derivatives as Type II c-Met Inhibitors. Bioorgan. Med. Chem. 2017, 25, 3195-3205. [CrossRef] [PubMed]

10. Nakazawa, Y.; Kawano, S.; Matsui, J.; Funahashi, Y.; Tohyama, Q.; Muto, H.; Nakagawa, T.; Matsushima, T. Multitargeting Strategy Using Lenvatinib and Golvatinib: Maximizing Anti-Angiogenesis Activity in a Preclinical Cancer Model. Cancer Sci. 2015, 106, 201-207. [CrossRef] [PubMed]

11. Parikh, P.K.; Ghate, M.D. Recent Advances in the Discovery of Small Molecule c-Met Kinase Inhibitors. Eur. J. Med. Chem. 2018, 143, 1103-1138. [CrossRef] [PubMed]

12. Darwish,H.W.; Abdelhameed, A.S.; Bakheit, A.H.; Alanazi, A.M. A New Method to Determine the New C-Met Inhibitor "Cabozantinib" in Dosage Form and Human Plasma via Micelle-Enhanced Spectrofluorimetry. RSC Adv. 2015, 5, 40484-40490. [CrossRef]

13. Tang, Q.D.; Duan, Y.L.; Wang, L.X.; O'Yang, Y.Q.; Wang, C.L.; Mei, H.; Tang, S.; Xiong, Y.H.; Zheng, P.W.; Gong, P.; et al. Synthesis and Antiproliferative Activity of Pyrrolo[2, 3-b]pyridine Derivatives Bearing the 1, 8-Naphthyridin-2-One Moiety. Eur. J. Med. Chem. 2018, 143, 266-275. [CrossRef] [PubMed]

14. Zhang, L.; Zhao, J.Y.; Zhang, B.C.; Lu, T.; Chen, Y.D. Discovery of [1, 2, 4] triazolo [3, 4-b][1, 3, 4] thiadiazole Derivatives as Novel, Potent and Selective c-Met Kinase Inhibitors: Synthesis, SAR Study, and Biological Activity. Eur. J. Med. Chem. 2018, 150, 809-816. [CrossRef] [PubMed]

15. Wang, L.X.; Xu, S.; Liu, X.B.; Chen, X.Y.; Xiong, H.H.; Hou, S.S.; Zou, W.S.; Tang, Q.D.; Zheng, P.W.; Zhu, W.F. Discovery of Thinopyrimidine-Triazole Conjugates as c-Met Targeting and Apoptosis Inducing Agents. Bioorg. Chem. 2018, 77, 370-380. [CrossRef] [PubMed]

16. Dadashpour, S.; Küçükkılınç, T.T.; Ayazgök, B.; Hosseinimehr, S.J.; Chippindale, A.M.; Foroumadi, A.; Irannejad, H. Discovery of Novel 1, 2, 4-Triazolo-1, 2, 4-Triazines with Thiomethylpyridine Hinge Binders as Potent c-Met Kinase Inhibitors. Future Med. Chem. 2019, 11, 1119-1136. [CrossRef] [PubMed]

17. Olmez, I.; Zhang, Y.; Manigat, L.; Benamar, M.; Brenneman, B.; Nakano, I.; Godlewski, J.; Bronisz, A.; Lee, J.; Abbas, T.; et al. Combined c-Met/Trk Inhibition Overcomes Resistance to CDK4/6 Inhibitors in Glioblastoma. Cancer Res. 2018, 78, 4360-4369. [CrossRef] [PubMed] 
18. Liu, X.B.; Kou, J.L.; Xiao, Z.; Tian, F.J.; Hu, J.Y.; Zheng, P.W.; Zhu, W.F. Design, Synthesis and Biological Evaluation of 6, 7-Disubstituted-4-Phenoxyquinoline Derivatives Bearing Pyridazinone Moiety as c-Met Inhibitors. Molecules 2018, 23, 1543. [CrossRef] [PubMed]

19. Ahmed, E.M.; Khalil, N.A.; Taher, A.T.; Refaey, R.H.; Nissan, Y.M. Triazolopyridazine Derivatives: Synthesis, Cytotoxic Evaluation, c-Met Kinase Activity and Molecular Docking. Bioorg. Chem. 2019, 92, 103272-103281. [CrossRef] [PubMed]

Sample Availability: Samples of all target compounds are available from the authors.

(C) 2019 by the authors. Licensee MDPI, Basel, Switzerland. This article is an open access article distributed under the terms and conditions of the Creative Commons Attribution (CC BY) license (http://creativecommons.org/licenses/by/4.0/). 